\title{
Capitalization of Public School Quality into Housing Prices: An Empirical Analysis Based on School District Housing for Public Primary Schools in Shanghai
}

\author{
Tiancheng Zhou \\ Shanghai Pinghe School, Shanghai, China \\ Email: zhoutch2001@sina.cn
}

How to cite this paper: Zhou, T. C. (2018). Capitalization of Public School Quality into Housing Prices: An Empirical Analysis Based on School District Housing for Public Primary Schools in Shanghai. Chinese Studies, 7, 286-327.

https://doi.org/10.4236/chnstd.2018.74025

Received: October 11, 2018

Accepted: November 10, 2018

Published: November 13, 2018

Copyright $\odot 2018$ by author and Scientific Research Publishing Inc. This work is licensed under the Creative Commons Attribution International License (CC BY 4.0).

http://creativecommons.org/licenses/by/4.0/

\begin{abstract}
This paper examines the capitalization of public school quality into housing prices in the specific context of China's compulsory education system and "district correspondence enrollment" policy, which stipulates a strict correspondence between residential estates and enrollment into public primary schools. Taking 344 neighborhoods in 7 main districts of Shanghai, China as its sample, this paper carries out detailed descriptive analysis of the data. It also employs the traditional Hedonic Price Model and 2SLS regression method to quantitatively calculate the exact capitalization rates while isolating eight non-school attributes affecting housing prices. It yields the conclusion that for every one-rank improvement in the quality of the corresponding public primary school, the average housing price of a neighborhood is projected to increase by $3.1 \%, 2.8 \%$, and $1.9 \%$, on the citywide, urban, and suburban scale, respectively. The capitalization effect of public school quality in housing prices is statistically significant, so the status-quo of the distribution of public educational resources in Shanghai is still considerably unequal. In the final section of this paper, the significance of this research is discussed and comprehensive policy recommendations and action plan are given in an attempt to mitigate the school district housing fever and educational inequality.
\end{abstract}

\section{Keywords}

Capitalization of Educational Quality, Housing Prices, School District Housing Fever, Shanghai, China, Hedonic Price Model, Two-Stage Least Squares (2SLS) Regression Method 


\section{Introduction}

There is a deeply-rooted tradition in the Chinese culture that regards excellence in education as almost the only key for children's success in life. Motivated by a host of stories such as "Meng Mu San Qian" and "Zi Lu Bai Shi" that tell the herculean efforts of ancient elites (and their entire families) in pursuing top education, Chinese parents of all socioeconomic status are willing to make every possible effort to secure their children's access to advanced educational resources. Because of the severely limited number of top-ranking public institutions, the fight for enrollment starts as early as for primary schools and creates great educational inequality, since the wealthy could afford admissions fees for their kids to get into better schools.

In an attempt to equalize access to public educational resources and enhance fairness in the enrollment process, the "district correspondence enrollment" policy was first adopted back in 1986 (Sixth National People's Congress, 1986). It divided residential estates into designated school districts in correspondence with nearby public primary and junior middle schools and stipulated that children living in the neighborhoods in a given school district enroll in the corresponding school. In 2014 (The State Council, 2012), this policy was strengthened to apply to $100 \%$ of the enrollment for public primary schools and over $90 \%$ of the enrollment for public junior middle schools.

The policy did almost eliminate school selection, but it also set the start of the School District Housing Fever, which is the soaring housing price in districts corresponding to Key Primary Schools (KPS) and Key Middle Schools (KMS). As a folk concept that has been in use for decades, KPS and KMS refer to those schools with capable teaching staff, favorable learning environment, and promising student body. Though there aren't clearly-defined criteria for a school to qualify as KPS or KMS, they are usually reputed locally. In October 2017, sales price averaged $¥ 113,000 / \mathrm{m}^{2}$ in Quandong neighborhood (Lianjia, 2017a) because the houses entail enrollment in Mingzhu primary school, the reputed best public primary school citywide. Yet in Weifang No.2 neighborhood which is out of the Mingzhu school district, the average sales price for apartments was only $¥ 69,800 / \mathrm{m}^{2}$ (Lianjia, 2017b). The two neighborhoods are only one block away, and both were constructed over 30 years ago, leaving their correspondence to schools as almost the only viable explanation for the apparent disparity in housing prices.

The reason is still the lack of high-quality educational resources and its uneven distribution as a public good. At its core, the designation of school district housing connects enrollment to estates, which is a private good, so that the desire of getting into KPS and KMS turns into an excess demand in the real estate markets of hot districts. In this way, enrollment is still unequal, even more so than before as housing prices are pushed to unprecedented levels.

China's real estate industry also set the stage of the country's school district 
housing fever. Since the industry's takeoff 30 years ago, it has been growing at an exponential level. From 2009 to 2013, the industry grew more than 22\%, of which second-hand sales of school district estates accounted for more than 13\% (National Data, 2018). According to Forbes, China has one of the highest home ownership rates in the world with over $90 \%$ of families owning their homes. This universal possession of estates means that most families can and do choose to sell off their houses in dissatisfactory districts and switch to districts with better schools, a process by which the feverish hike of school district housing prices takes place.

These observations render it crucial to study the School District Housing Fever, since a balanced educational system is key to maintaining equality in educational opportunities. Also, higher social mobility will give the society a boost in human resources, as the poor will no longer be prevented from receiving quality education by unaffordable housing prices and kept at the bottom for generations.

Facing the deeply-rooted problem of school district housing, the Chinese central government has been taking a variety of measures. In February 2016, Shanghai adopted a new policy (Shanghai Education Commission, 2016) stipulating that only one enrollment opportunity is available for each estate in every five years, regardless of changes in its ownership. This means that after one child is enrolled, the house will be ineligible for enrollment for five years. In terms of the educational system, the government is trying to equalize the qualities of schools across districts. One measure was to join each district with a higher-quality school with a district corresponding to a lower-quality school and randomly enroll children in the joint district into either of the two schools. This way, the disparity in school quality can be evened out theoretically. However, these policies are still of limited effect in cooling down school district housing in real practice.

Therefore, by engaging in a scientific examination of the cause and development of the phenomenon, this paper aspires to propose several possible remedies based on supply-side economics so that the welfare of the entire society can be maximized.

\section{Literature Review}

As a basic societal good, public education is financed by the government with its tax revenue and is provided to all the citizens. These characteristics render it a typical public good in classical economic theory. Public education creates a positive externality: As more people are educated, the society's labor productivity increases while its crime rate tends to fall, which benefits other members of the society. Therefore, other assets absorb the cost of public education, and the prices of these assets rise consequently. This economic phenomenon is referred to as capitalization of public goods (Liu \& Yi, 2011). China’s school district housing 
fever, in which housing prices are higher in districts with higher-quality public schools, is a manifestation of capitalization of public goods.

\subsection{Background on China's Contemporary Public Educational System}

China's school district housing fever arises in the context of the China's contemporary public educational system, which underwent four stages of development (Zou, 2008).

The first stage spanned from 1977 to 1985 and witnessed the reorganization of China's Public Educational System. In this period, more than 230 higher education institutions were established, and a number of high-quality primary, middle and high schools were formally recognized and distinguished by the government to the general public at district and city levels. These developments created a social atmosphere highly passionate for education, and most families competed fiercely for high-quality educational resources.

The second stage was from the year of 1985 to 1989 and witnessed the reorganization of China's Public Educational System. On July 1 $1^{\text {st }}, 1986$, the Compulsory Education Law of the People's Republic of China was formally promulgated, which guaranteed nine years of compulsory education for every Chinese citizen and instructed its detailed implementation: Residence estates were divided into designated school districts in correspondence with nearby public elementary and junior middle schools, and children living in a school district can enroll in the corresponding school without selection. The main purpose of the Law was to enhance educational fairness for low-income families by replacing selective enrollment fees with the relatively fixed locations of residence estates. However, since estates are private commodities available for purchase, the adoption of the Law set the start of China's school district housing fever.

The years 1990 through 2003 can be regarded as the third stage where the industrialization of China's Public Educational System took place. The Decision of the Central Committee of the Communist Party of China on the Acceleration of the Development of the Tertiary Industry of 1992 classified education as a tertiary industry. Education was thereby redefined as a constituent of "social productivity" instead of a former "superstructure". Under this principle, the government prioritized educational outcome ahead of educational fairness. Also, the scale and capacity of the educational system was rapidly enlarged. This led to an industrialization of Chinese education. Meanwhile, with the legalization of private institutions for basic education in 1999, the regulation of the educational system loosened and the competition for high-quality educational resources was fueled as enrollment fees were collected by many institutions. The prices of school district housing remained high through this period.

From 2003 until this present day, the development of China's Public Educational System is in its fourth stage. Into the $21^{\text {st }}$ century, the government has reemphasized the fairness of public education. In May 2005, the Ministry of 
Education formally issued Opinions on Further Promoting the Balanced Development of Compulsory Education. It placed a total ban on any kind of enrollment selections such as fees or exams and ordered a stricter enforcement of the "district correspondence enrollment" policy (Ministry of Education of People's Republic of China, 2014a, 2014b) (refer to the Introduction of this paper for an explanation): School districts were re-specified, and children are obliged to enroll accordingly. Up until 2014 (General Office of the Ministry of Education of People's Republic of China, 2014), this principle has been applied to $100 \%$ of the enrollment of public primary schools and $95 \%$ of that of public junior middle schools in 19 major cities across the country.

As of 2017 when this paper is composed, an average child can enroll in high-quality elementary education either by paying for private education or by buying school districts housing for public school. However, in 2016, the average tuition fee of private primary schools in Shanghai was $¥ 24,500 \quad(\approx 3720)$ per semester and still rising (which is more than ten times the tuition fee charged by public education). For most families, this sum was a significant economic burden, so the competition for entrance into high-quality public schools and corresponding houses remained and intensified. From March 2015 to March 2016, the average price for high-quality primary school district housing in Shanghai rose by over $62.8 \%$, equivalent to about $¥ 26,000 \quad(\approx \$ 4000)$ per square meter (Xingdd, 2016) (Figure 1).

\subsection{Western Researches-Overview and Analysis}

Over the past 60 years, with the development of economic theories and its applications, a large number of Western researches were conducted on the capitalization of public education on estate prices.

In 1956, American geo-economist Charles Tiebout became the first to put forward a theoretical model (Tiebout, 1956) to describe the provision of public goods. He observed that local residents automatically move away from

\section{Average Price for Key Primary School District Housing in Shanghai}

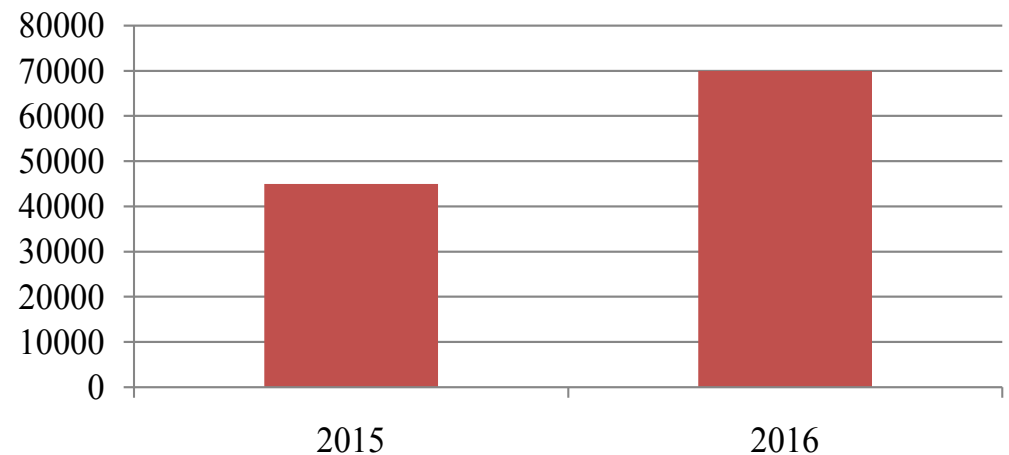

Figure 1. Average price for key primary school district housing in Shanghai, 2015-2016. 
communities with dissatisfactory public services to where the public goods best satisfies their preferences, a process which he called "vote with their feet". $\mathrm{He}$ hypothesized a corresponding capitalization effect in the prices of the estates and suggested that a market solution can exist for public goods at the local level, where the government and consumer-voters can communicate their supply and demand of public services through the market of real estates across different communities.

Oates (1969) empirically verified the Tiebout hypothesis in 1969. By working with data from fifty-three residential communities in northeastern New Jersey, Oates concluded that local property values bear a significant negative relationship to the effective tax rate and a significant positive correlation with expenditure per pupil of the public schools.

From the 1970s onwards, as the capitalization of public education on estate prices arose in more places, many scholars took different perspectives and approaches in investigating the phenomenon. Most of the published findings confirmed the positive effect of school quality on the prices of private estates, while the precise magnitude and choice of variables were varied.

Oates used expenditure per pupil as the dominant factor in measuring a school's quality, which focused on the school's educational input. However, Rosen \& Fullerton (1977) argued that proficiency test scores are a better measure of school quality, because the educational output effectively takes into account both the school's efforts and the unquantifiable learning environment and peer effects the school offers. In this way, their 1977 paper obtained results with a significant level as high as $90 \%$.

Rosen and Fullerton's finding was cited by a large body of researches, and $\mathrm{K}-12$ student achievement measures replaced expenditure to become the most commonly-used factor in subsequent studies on the relation between estate prices and public school quality. Haurin \& Brasington (1996) used the pass rate on a ninth-grade statewide proficiency test and calculated that the capitalization of school quality occurred on a per lot basis rather than per square foot of land. It is worth noting that their study separated the capitalization effects in the prices of the estates caused by other variables, such as the house's structural characteristics and its distance to the city's CBD. In this way, they were able to isolate the precise effect of school quality on house prices.

Another measure of school quality is the value added, which refers to the marginal effect of school education on students' achievements over a given time period. In this sense, schools with higher value added are better, meaning that they boost students' achievements to a greater level apart from the impact of their families or innate aptitudes. Downes \& Zabel (2002) used a sample of 1173 house prices data in the Chicago metropolitan area and found that higher average levels of academic achievement raise house values, but value-added did not. Brasington (2006) arrived at a similar conclusion: Using data from 310 school districts and 77,000 house transactions in 2000 in Ohio, they found that households consistently value a school's average proficiency test scores and expendi- 
tures instead of the value-added. They calculated that the elasticity of house prices with respect to school expenditures was 0.49 , and an increase in test scores by one standard deviation raised house prices by $7.1 \%$, while the effect of value added on house prices was insignificant. Hayes \& Taylor (1996), however, found that in addition to absolute achievement levels, homebuyers are willing to pay an extra premium for value added. Other researches that discussed this method include Boardman \& Murnane (1979), Aitkin \& Longford (1986), and Hanushek, Rivkin, \& Taylor (1996).

There are other notable studies that took unique perspectives. Dubin \& Goodman (1982) studied the impact of twelve variables of crime and twenty-one variables of education on house prices in Baltimore and found that these variables substantially explain house prices. Black (1999) studied housing price at the convergence of two or more school districts so that the effects of housing and geographical characteristics could be isolated. He calculated a slight capitalization effect of school quality $50 \%$ less than the average rate obtained in other studies. Dills (2004) showed that improved performance on college entrance exams was associated with increased overall housing value aggregated to the district level.

More recent researches took a more practical angle as scholars evaluated the outcomes of school district policies. In 2008, Hu \& Yinger (2008) investigated the impact of school district consolidation in New York State since 1990 on the capitalization effects of public schools. They found that the policy boosted house prices by $25 \%$ in very small districts but had no marked effect in those with more than about 1700 pupils. In 2011, Nguyen-Hoang \& Yinger (2011) made a comprehensive review of empirical studies on the capitalization of school quality into house prices since 1999 and confirmed that significant capitalization effects did exist especially for educational outputs. But they concluded that although challenges still remained, much progress had been made on the issue.

Although past researchers used different types and scopes of the variables in calculating the capitalization effect of school district housing, the hedonic price model, or hedonic price regression, was the commonly-used methodology to determine the relationship of each housing attribute to its transaction price and measure each of these relationships isolated from the effects of other attributes (Monson, 2009). In this case, the model can isolate the effects of other attributes and measure the net capitalization effect of the quality of public education on housing prices.

\subsection{Chinese Researches-Overview and Analysis}

A large body of Chinese literature studies the capitalization effect of public education in estate prices. Due to the relatively later emergence of the capitalization effects in China, most Chinese researchers employed the hedonic price regression model and similar methodologies as Western researches. But again, their perspectives varied. 
An early research conducted by Feng \& Lu (2010) in 2010 studied monthly panel data of Experimental Model Senior High Schools (EMSHS) and corresponding housing prices in 52 school districts across Shanghai. Their study marked the presence of capitalization of public education and calculated an average rise of $6.9 \%$ of housing price when an extra leading EMSHS is added to district. Wen, Yang, \& Qin (2013), Huang (2010), Meng \& Jia (2014), and Wang, Ge, \& Zhang (2010) attained similar results using data in Hangzhou, Xi'an, Guangzhou, and Nanjing, respectively.

Liu \& Sun (2015) based their study on the panel data of second-hand deals of school district housing in Wuhou District, Chengdu. They concluded that public education did have a marked price premium on the estates price, and the amount of premium showed the Matthew effect, where top schools have a significant positive effect on the price of estates, while price premium of average schools may be tiny or even negative since people are selling the estates off in exchange for those in better school districts. Using data from 202 school districts in Hangzhou City Area, Mao, Luo, \& Pan (2014) calculated the price premiums of sought-after middle and primary schools to be $25.5 \%$ and $12.8 \%$ and concluded that the presence of private education aggravated the local capitalization effect.

\subsection{Thoughts and Inspirations}

After a thorough review of the background and the status quo of China's school district housing fever in theoretical and empirical lens, we came to the understanding that the problem has been chronic and prevalent across the country, limiting low-income families' access to high-quality educational resources economically. We found that no researches has been conducted on Shanghai's public primary school district housing, so our research paper has practical importance in investigating the local phenomenon at the very basis of education. Also, since Shanghai has a socioeconomic development level ahead of other cities in China, this paper can also shed light on studying the problem in other areas or nationwide. Furthermore, the government's past policy attempts to cool down the housing prices mainly took a demand-side approach but haven't produced effective outcomes so far. Seeing that the latest Western studies have focused on evaluating and advising school district policies, we also considered some of the impacts of recent Chinese policies and used our empirical findings to discuss future policy advice.

The body of past literature guided us of the research methodology. Knowing from existing researches that a wide range of housing attributes can affect house prices, we used hedonic price model to isolate their effects so that the pure effect of public education can be obtained. Specifically, we excluded the effects of eight non-school attributes, namely distance to the corresponding public primary school, distance to the CBD of the district, property management fee, green coverage ratio, elevator, residential area, floor area ratio, and building age. 


\section{Methodology}

\subsection{Data and Variable Description}

This study selects three main urban districts (namely Xuhui, Huangpu, and Changning) and four main suburban districts (namely Minhang, Jiading, Songjiang, and Baoshan) in Shanghai as its study areas. Among the city's total fifteen districts, the seven are chosen according to their scale of the school district housing fever, which is estimated from the size of the population as well as the number and quality of public primary schools in the district. It is believed that the capitalization effect is more pronounced and observable in districts with a larger population and more schools of higher qualities. Another factor in selecting the study areas is the accessibility and sufficiency of data. Major districts like Pudong weren't included in consideration due to the lack of data arising from its large floating population and other factors. According to existing research, the capitalization effect is only significant for schools of relatively higher quality; it is likely to be negligent or negative for middle- or lower-quality school districts since people are not considering the schools as a factor in real estate purchase of even selling of their estates for those in better school districts. So the top 30\% of primary schools in each urban district and $\sim 10 \%$ of primary schools in each suburban district and their corresponding neighborhoods are studied in this paper for a significant causational effect. That said, the sample of this paper covers a total of 10.08 million residents and 43 school districts ${ }^{1}$.

In this paper, the dependent variable is the average housing price of a neighborhood. The independent variables include the quality of the corresponding public primary school and eight other factors classified into three aspects according to the framework of the hedonic pricing model: structure, neighborhood, and location. The eight factors are chosen mainly based on the accessibility of standardized data for neighborhoods across the city. For example, although better interior decoration counts towards a higher housing price, there is no quantifiable data to measure or score it, while a simple dummy variable is too arbitrary. Nevertheless, the eight factors are balanced so that they reflect different parts in housing prices. For instance, property management fee accounts for the social status of the residents' composition, while green coverage ratio reflects the quality of the neighborhood's environment.

Since the purpose of this study is to measure the capitalization effect of public school quality into housing prices, the quality of the corresponding public primary school is the main independent variable to be studied separate from the other non-school attributes, which are treated as control variables. Similar to studies Wen \& Chen (2014); Wen, Zhang, \& Zhang (2014); and Wen \& Tao (2015), three methods (actual data, scoring method, and dummy variable) are adopted to quantify the variables of the sample as accurately as possible. Specifically, the actual data of housing price, residential area, building age, property

${ }^{1}$ Data last updated by the end of 2016; same for other data in this paper if not otherwise specified. 
management fee, floor area ratio, green coverage ratio, the distance to the corresponding public primary school, and the distance to the district's CBD are used to measure their contents directly. Since there is no standardized test for primary school students' academic performances in China, the quality of the corresponding public primary school is given by a score equal to its rank within the district, which can reflect its educational quality relative to other schools in Shanghai.

The variable names, classification, description, quantification, and expected signs and scales are all listed below in Table 1, and the comprehensive data is provided in the Appendix. The rankings of the schools are obtained from 51test.net, China's largest educational portal website and Hatong-shsx, one of Shanghai's largest Wechat Official Accounts providing information on examinations, and educational activities with over 2.63 million subscribers (Hatong Shanghai Shengxue, 2017). The correspondence between the schools and the neighborhoods and the estimated average housing prices in each neighborhood are obtained from the study conducted by sh.bendibao.com, which is a trusted portal website providing all-rounded information for local life such as transportation and real estate trading. Referring to portal websites for these data is justified because school-related information is not released by government agencies so as not to intensify the school district housing fever. The sources cited in this paper are credible since they are universally-recognized by a large user base and the information they provide are also obtained from careful investigations and analyses. The housing information including sales prices and other relevant characteristics is obtained from Fang.com, one of the largest and most renowned real estate information platform covering 642 cities in China with over 6.5 million active subscribers (Fang, 2017). For each neighborhood, the house whose price is closest to the neighborhood average is selected as the representative. In order to ensure the unity of data, this paper only studies high-rise housing apartments and excludes villas and townhouses. These considerations render the choice and analysis of variables in this paper considerably relevant and complete.

\subsection{Descriptive Statistics Analysis of Independent Variables}

In this section and the one that follows, the data with be analyzed statistically in three dimensions: citywide, urban, and suburban, so that the conclusions and implications are specific and distinguishable.

The descriptive analysis on the citywide scale is given below in Table 2. The average school district housing price is $76,949.81 \mathrm{RMB} / \mathrm{m}^{2}$, with a maximum value of $150,621 \mathrm{RMB} / \mathrm{m}^{2}$ and a minimum value of $28,641 \mathrm{RMB} / \mathrm{m}^{2}$. The quality of the corresponding public primary school, given by its ranks, has an average of 5 , maximum of 11 and minimum of 1 , which is consistent with our sampling of the data. The averages of distance to the corresponding public primary School, distance to the district's $\mathrm{CBD}$, property management fee, green coverage ratio, elevator, residential area, floor area ratio, and building age are, respectively, 
Table 1. Variable description.

\begin{tabular}{|c|c|c|c|}
\hline $\begin{array}{c}\text { Variable } \\
\text { Classification }\end{array}$ & Variable Name & $\begin{array}{c}\text { Variable Description and } \\
\text { Quantification }\end{array}$ & $\begin{array}{c}\text { Unit and } \\
\text { Expected Sign }\end{array}$ \\
\hline $\begin{array}{l}\text { Main Independent } \\
\text { Variable }\end{array}$ & $\begin{array}{l}\text { Quality of the } \\
\text { Corresponding Public } \\
\text { Primary School }\end{array}$ & $\begin{array}{l}\text { A score equal to the rank of the } \\
\text { school in the entire city. The lower } \\
\text { the score, the higher the } \\
\text { school's quality }\end{array}$ & N/A, - \\
\hline Dependent Variable & Housing Price & Sales price of a given house & $\begin{array}{l}\mathrm{RMB} / \mathrm{m}^{2} \\
\mathrm{~N} / \mathrm{A}\end{array}$ \\
\hline Independent & $\begin{array}{l}\text { Distance to the } \\
\text { Corresponding Public } \\
\text { Primary School }\end{array}$ & $\begin{array}{l}\text { Straight-line distance from the } \\
\text { neighborhood center to its } \\
\text { corresponding public primary } \\
\text { school }\end{array}$ & Meters, - \\
\hline $\begin{array}{l}\text { Variables- } \\
\text { Location }\end{array}$ & & $\begin{array}{l}\text { Straight-line distance from the } \\
\text { neighborhood center to the CBD }\end{array}$ & \\
\hline Characteristics & $\begin{array}{l}\text { Distance to the CBD } \\
\text { of the District }\end{array}$ & $\begin{array}{l}\text { of the district, usually taken as the } \\
\text { Wanda Plaza, the major } \\
\text { commercial and } \\
\text { recreational landmark }\end{array}$ & Meters, - \\
\hline \multirow{3}{*}{$\begin{array}{l}\text { Independent } \\
\text { Variables- } \\
\text { Neighborhood } \\
\text { Characteristics }\end{array}$} & $\begin{array}{l}\text { Property Management } \\
\text { Fee }\end{array}$ & $\begin{array}{c}\text { The fee every household has to pay } \\
\text { for estate upkeep and } \\
\text { neighborhood management }\end{array}$ & $\begin{array}{c}\mathrm{RMB} / \mathrm{m}^{2} \\
\text { per month, + }\end{array}$ \\
\hline & Green Coverage Ratio & $\begin{array}{c}\text { The percentage of open space } \\
\text { covered by greenness in a } \\
\text { neighborhood }\end{array}$ & $\%,+$ \\
\hline & Elevator & $\begin{array}{l}\text { Dummy variable is equal to } 1 \\
\text { if the neighborhood has elevators } \\
\text { or } 0 \text { if otherwise }\end{array}$ & $\mathrm{N} / \mathrm{A},+$ \\
\hline \multirow{3}{*}{$\begin{array}{l}\text { Independent } \\
\text { Variable- } \\
\text { Structural } \\
\text { Characteristics }\end{array}$} & Residential Area & Floor area within a house & $\mathrm{m}^{2},-$ \\
\hline & Floor Area Ratio & $\begin{array}{l}\text { Ratio of a building's gross floor } \\
\text { area to the size of the piece of land } \\
\text { upon which it is built } \\
\text { (Standard definition) }\end{array}$ & N/A, - \\
\hline & Building Age & $\begin{array}{c}\text { Number of years since the } \\
\text { building was built }\end{array}$ & Years, - \\
\hline
\end{tabular}

748.13 meters, 2141.80 meters, $2 \mathrm{RMB} / \mathrm{m}^{2}$ per month, $34.03 \%, 0.62,92.41 \mathrm{~m}^{2}$, 2.21 , and 19.54 years.

The descriptive analysis for the urban areas is given below in Table 3. Most notably, the average school district housing price is $88,311.57 \mathrm{RMB} / \mathrm{m}^{2}, 14.77 \%$ higher than the average value citywide.

The descriptive analysis for the suburban areas is given below in Table 4 . The average school district housing price is $49,993.49 \mathrm{RMB} / \mathrm{m}^{2}$, over $35 \%$ lower than the average value citywide. In comparison with the data of the urban areas, the average green coverage ratio and distance to the district's CBD are greater in the suburban places while the property management fee is cheaper and there are fewer elevators. Also, the public schools in suburban areas generally have lower ranks than those in urban areas, reflecting the relative lack of educational resources in suburban areas. As these patterns match properly with the actual 
Table 2. Descriptive analysis of independent variables, citywide.

\begin{tabular}{cccccc}
\hline Variable & Unit & Average & $\begin{array}{c}\text { Standard } \\
\text { Deviation }\end{array}$ & $\begin{array}{c}\text { Maximum } \\
\text { Value }\end{array}$ & $\begin{array}{c}\text { Minimum } \\
\text { Value }\end{array}$ \\
\hline $\begin{array}{c}\text { Quality of the } \\
\text { Corresponding Public } \\
\text { Primary School }\end{array}$ & no unit & 20.31 & 11.41 & 44 & 1 \\
$\begin{array}{c}\text { Housing Price } \\
\text { Distance to the }\end{array}$ & RMB/m ${ }^{2}$ & $76,949.81$ & $24,548.04$ & 150,621 & 28,641 \\
$\begin{array}{c}\text { Corresponding Public } \\
\text { Primary School }\end{array}$ & Meters & 748.13 & 504.75 & 4600 & 10 \\
$\begin{array}{c}\text { Distance to the } \\
\text { District's CBD }\end{array}$ & Meters & 2141.80 & 1439.08 & 7700 & 70 \\
$\begin{array}{c}\text { Property Management Fee } \\
\begin{array}{c}\text { RMB/m } \\
\text { Green Coverage Ratio }\end{array}\end{array}$ & per month & 2 & 1.72 & 14.8 & 0.3 \\
Elevator & no unit & 0.52 & 0.50 & 1 & 10 \\
Residential Area & m ${ }^{2}$ & 92.41 & 50.92 & 404 & 0 \\
$\begin{array}{c}\text { Floor Area Ratio } \\
\text { Building Age }\end{array}$ & no unit & 2.21 & 1.09 & 8.9 & 0.36 \\
\hline
\end{tabular}

Table 3. Descriptive analysis of independent variables, urban.

\begin{tabular}{|c|c|c|c|c|c|}
\hline Variable & Unit & Average & $\begin{array}{l}\text { Standard } \\
\text { Deviation }\end{array}$ & $\begin{array}{c}\text { Maximum } \\
\text { Value }\end{array}$ & $\begin{array}{l}\text { Minimum } \\
\text { Value }\end{array}$ \\
\hline $\begin{array}{l}\text { Quality of the } \\
\text { Corresponding Public } \\
\text { Primary School }\end{array}$ & no unit & 14.53 & 7.58 & 29 & 1 \\
\hline Housing Price & $\mathrm{RMB} / \mathrm{m}^{2}$ & $88,311.57$ & $18,676.47$ & 150,621 & 50,933 \\
\hline $\begin{array}{l}\text { Distance to the } \\
\text { Corresponding Public } \\
\text { Primary School }\end{array}$ & Meters & 650.94 & 383.03 & 1900 & 10 \\
\hline $\begin{array}{l}\text { Distance to the } \\
\text { District's CBD }\end{array}$ & Meters & 2059.59 & 1376.79 & 7700 & 70 \\
\hline Property Management Fee & $\begin{array}{c}\mathrm{RMB} / \mathrm{m}^{2} \\
\text { per month }\end{array}$ & 2 & 1.96 & 14.8 & 0.13 \\
\hline Green Coverage Ratio & $\%$ & 32.72 & 9.17 & 70 & 10 \\
\hline Elevator & no unit & 0.62 & 0.49 & 1 & 0 \\
\hline Residential Area & $\mathrm{m}^{2}$ & 92.10 & 53.37 & 404 & 18 \\
\hline Floor Area Ratio & no unit & 2.47 & 1.08 & 5.68 & 0.38 \\
\hline Building Age & Years & 20.80 & 13.83 & 178 & 1 \\
\hline
\end{tabular}

environmental and economic situations in Shanghai, they prove the validity and real-life significance of the sample and data sources of this paper and lay the foundation for following technical analyses.

The number of KPS in each district of Shanghai is listed below in Table 5 and illustrated in Figure 2. The four districts with the most KPS are Xuhui, Huangpu, Pudong, and Yangpu in order. These districts are all in the urban area and share the characteristic of advanced socioeconomic activities and educational 
Table 4. Descriptive analysis of independent variables, suburban.

\begin{tabular}{|c|c|c|c|c|c|}
\hline Variable & Unit & Average & $\begin{array}{l}\text { Standard } \\
\text { Deviation }\end{array}$ & $\begin{array}{l}\text { Maximum } \\
\text { Value }\end{array}$ & $\begin{array}{l}\text { Minimum } \\
\text { Value }\end{array}$ \\
\hline $\begin{array}{l}\text { Quality of the } \\
\text { Corresponding Public } \\
\text { Primary School }\end{array}$ & no unit & 34.23 & 5.98 & 44 & 22 \\
\hline Housing Price & $\mathrm{RMB} / \mathrm{m}^{2}$ & $49,993.49$ & $13,077.58$ & 80,060 & 28,461 \\
\hline $\begin{array}{l}\text { Distance to the } \\
\text { Corresponding Public } \\
\text { Primary School }\end{array}$ & Meters & 978.72 & 662.43 & 4600 & 40 \\
\hline $\begin{array}{l}\text { Distance to the } \\
\text { District's CBD }\end{array}$ & Meters & 2336.86 & 1566.97 & 7100 & 110 \\
\hline Property Management Fee & $\begin{array}{l}\mathrm{RMB} / \mathrm{m}^{2} \\
\text { per month }\end{array}$ & 1.07 & 0.71 & 3.5 & 0.2 \\
\hline Green Coverage Ratio & $\%$ & 37.16 & 8.72 & 70 & 17 \\
\hline Elevator & no unit & 0.30 & 0.46 & 1 & 0 \\
\hline Residential Area & $\mathrm{m}^{2}$ & 93.13 & 44.82 & 303 & 29 \\
\hline Floor Area Ratio & no unit & 1.57 & 0.86 & 8.9 & 0.36 \\
\hline Building Age & Years & 16.55 & 6.45 & 38 & 2 \\
\hline
\end{tabular}

Table 5. Number of key primary schools (kps) in shanghai, by district.

\begin{tabular}{cccccc}
\hline District & Number & District & Number & District & Number \\
Xuhui & 14 & Pudong & 14 & Huangpu & 13 \\
Yangpu & 10 & Minhang & 9 & Jiading & 9 \\
Baoshan & 8 & Jing'an & 7 & Putuo & 6 \\
Jinshan & 6 & Songjiang & 6 & Hongkou & 5 \\
Changning & 4 & Fengxian & 3 & Qingpu & 2 \\
\hline
\end{tabular}

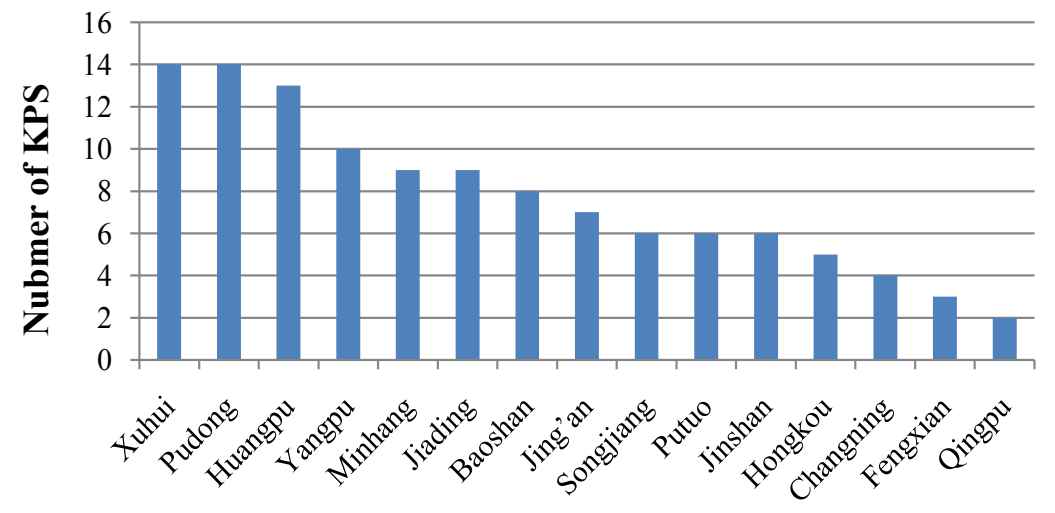

\section{Districts}

Figure 2. Number of KPS in Shanghai, by district.

resources, and thus relatively higher housing prices. The suburban districts, by contrast, generally have less developed economies and lower-quality educational resources. 
Figures 3-4 offer a clearer observation of the more pronounced capitalization effect of public school quality into housing prices in the urban districts by visualizing the distribution of housing prices. The distribution of housing prices in Huangpu District is illustrated graphically below in Figure 3 where the peaks and troughs correspond to the different housing prices of neighborhoods in different school districts and the trend of change between them. One school may correspond to several neighborhoods whose housing prices decrease as the distance to the school increases. The conspicuous peaks are likely to be caused by sought-after schools whose housing prices are significantly higher than those of others. The varying heights of the peaks illustrate the different housing prices for different schools.

Figure 4 and Figure 5 illustrate the distributions of housing prices in Xuhui and Changning Districts, respectively. Similar to Figure 3, the peaks and troughs correspond to neighborhoods in different school districts. But the unique characteristic setting these two districts apart from Huangpu is the differences between housing prices of different neighborhoods are obvious in Xuhui and Changning. In Huangpu, however, there isn't such sharp difference.

\subsection{Hedonic Price Model}

To calculate the exact capitalization rates, the traditional Hedonic Price Model is employed. The basic assumption of our econometric model assumes that housing price reflect the market values of public school quality and other characteristics.

After referring to existing researches on real estate valuation and considering the quantification of the variable studied here, the logarithm functional is used to establish the basic model. Specifically, positive and continuous independent variables (e.g., distance, building age, floor area ratio) are adopted in logarithmic form, while the variables quantified through scoring or dummy variables (namely quality of corresponding public primary school and elevator) are adopted

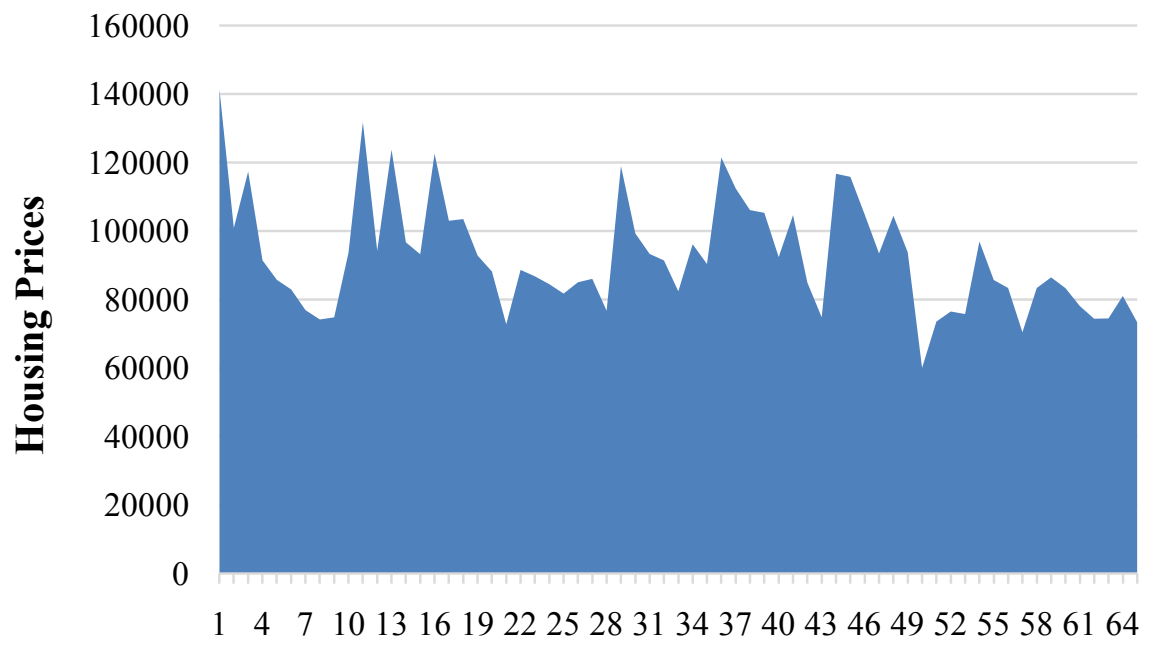

Figure 3. Distribution of housing prices in Huangpu district. 


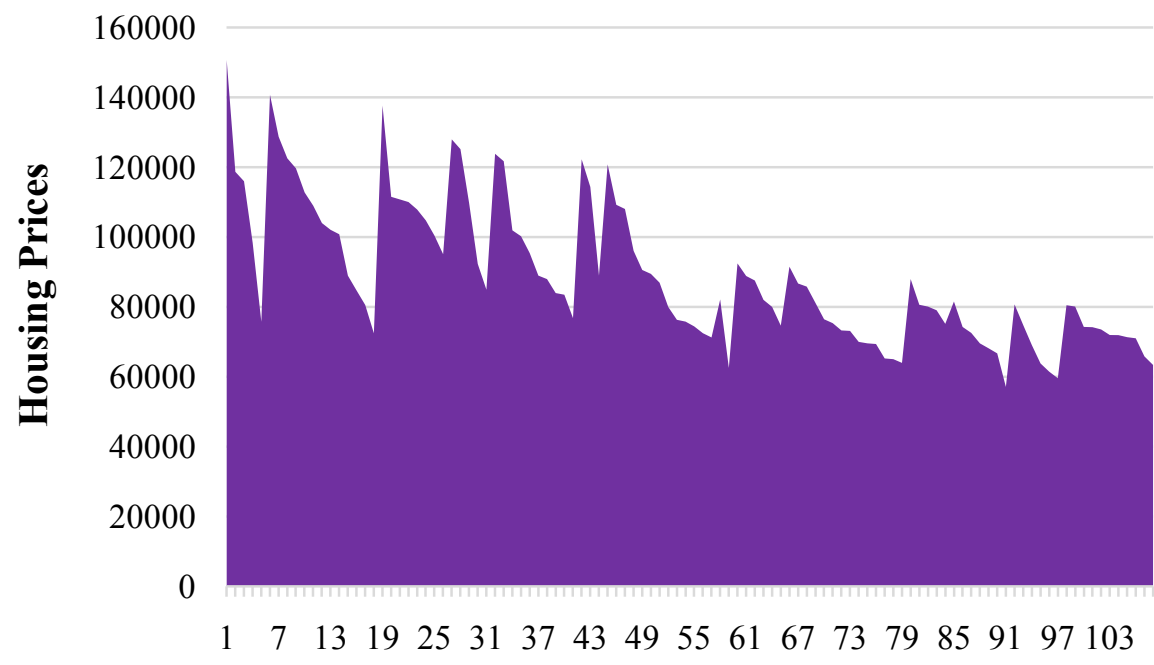

Figure 4. Distribution of housing prices in Xuhui district.

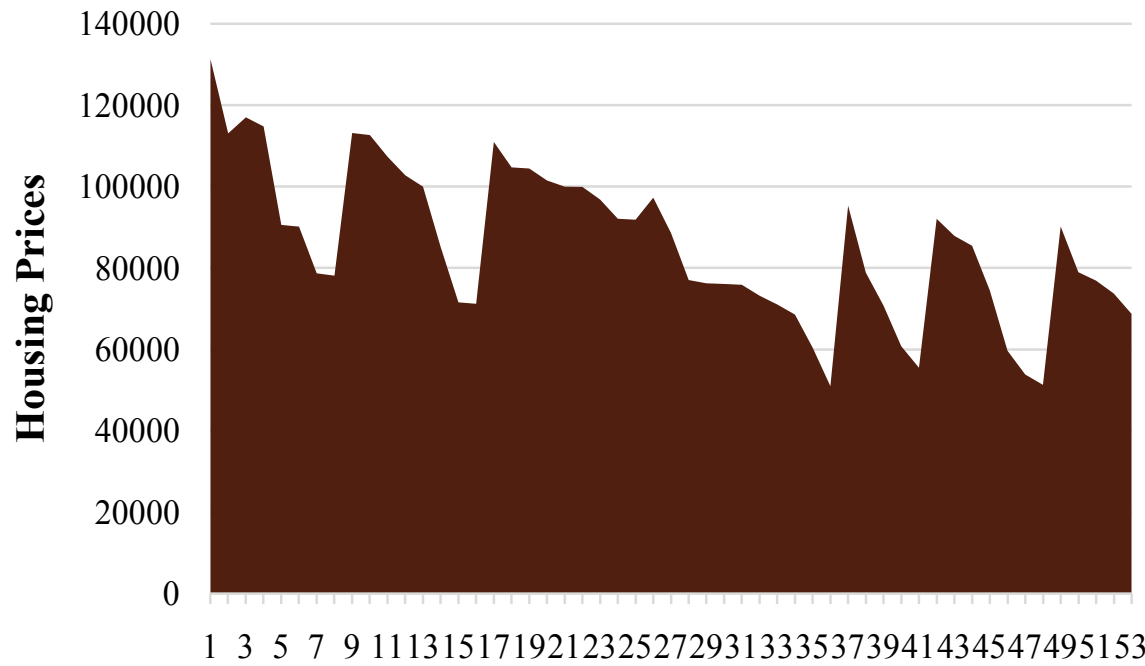

Figure 5. Distribution of housing prices in Changning district.

in linear form. We assume a standard form for the empirical hedonic house price function:

$$
\ln P_{i j}=a X_{j}+\sum b_{k} X_{i j k}+b_{0}+\varepsilon
$$

where, $\ln P_{i j}$ is the natural logarithm of housing price for the representative house in the $i^{\text {th }}$ neighborhood that corresponds to school $j . X_{j}$ is the quality of school $j$, and $X_{i j k}$ is the set of the seven control variables of the representative house in the $i^{\text {th }}$ neighborhood that corresponds to school $j . \varepsilon$ is the error term, and $a$ is the key coefficient to be estimated.

This paper uses two-stage least squares (2SLS) regression method (an extension of the OLS method) to compute the coefficients in order to avoid the endogeneity bias of education quality and quantity. The following results are obtained using the data processing tools in Excel and are analyzed on the citywide scale, in the urban areas, and in the suburban areas. 
The results of regression analysis and variance analysis on the citywide scale are given in Table 6 and Table 7, respectively. The variance analysis confirms that the model fits very well with the experimental data and so the coefficients it yielded can be used to explain the sample. Every coefficient fits with its expected sign, and their P-values further verify that most coefficients are statistically significant. Specifically, the coefficient of the quality of the corresponding public primary school is -0.031 , meaning that housing price increases by $3.1 \%$ for a one-rank improvement of its corresponding school (which is equivalent to its numerical rank decreasing by 1 ).

The residual plot and line fit plot for the variable "Quality of the Corresponding Public Primary School" are cited below in Figure 6 and Figure 7 to illustrate its statistical significance.

The results of regression analysis and variance analysis in the urban areas are given in Table 8 and Table 9, respectively. The variance analysis confirms that the model fits very well with the experimental data and so the coefficients it yielded can be used to explain the sample. The P-values of the coefficients further verify that most of them are statistically significant and fit with their expected signs. Specifically, the coefficient of the quality of the corresponding public primary school is -0.028 , meaning that housing price increases by $2.8 \%$ for a one-rank improvement of its corresponding school (which is equivalent to its numerical rank decreasing by 1 ).

Table 6. Regression analysis, citywide.

\begin{tabular}{ccccc} 
Variable & Coefficient & $\begin{array}{c}\text { Standard } \\
\text { Deviation }\end{array}$ & t Stat & P-value \\
\hline Intercept & 12.156 & 0.199 & 61.061 & $2.862 \mathrm{E}-183$ \\
$\begin{array}{c}\text { Quality of the Corresponding } \\
\text { Public Primary School }\end{array}$ & -0.031 & 0.001 & -33.790 & $8.616 \mathrm{E}-110$ \\
$\begin{array}{c}\text { Distance to the Corresponding } \\
\text { Public Primary School }\end{array}$ & -0.027 & 0.010 & -2.657 & 0.008 \\
$\begin{array}{c}\text { Distance to the District's CBD } \\
\text { Property Management Fee }\end{array}$ & -0.007 & 0.011 & -0.663 & 0.508 \\
Green Coverage Ratio & 0.029 & 0.019 & 1.536 & 0.125 \\
Elevator & 0.002 & 0.032 & 0.072 & 0.942 \\
Residential Area & 0.003 & 0.022 & 0.123 & 0.902 \\
Floor Area Ratio & -0.003 & 0.024 & -0.106 & 0.916 \\
Building Age & -0.016 & 0.020 & -0.775 & 0.439 \\
\hline
\end{tabular}

Table 7. Variance analysis, citywide.

\begin{tabular}{cccccc}
\hline Name & df & SS & MS & F & Significance F \\
\hline Regression Analysis & 9 & 44.456 & 4.940 & 208.954 & $1.9458 \mathrm{E}-131$ \\
Residuals & 334 & 7.896 & 0.024 & & \\
Sum & 343 & 52.352 & & & \\
\hline
\end{tabular}


Table 8. Regression analysis, urban.

\begin{tabular}{ccccc}
\hline Variable & Coefficient & $\begin{array}{c}\text { Standard } \\
\text { Deviation }\end{array}$ & t Stat & P-value \\
\hline $\begin{array}{c}\text { Intercept } \\
\text { Quality of the Corresponding }\end{array}$ & 12.210 & 0.207 & 59.068 & $8.565 \mathrm{E}-142$ \\
$\begin{array}{c}\text { Public Primary School } \\
\text { Distance to the Corresponding }\end{array}$ & -0.028 & 0.001 & -22.069 & $6.56 \mathrm{E}-59$ \\
$\begin{array}{c}\text { Public Primary School } \\
\text { Distance to the District's CBD }\end{array}$ & -0.012 & 0.010 & -1.146 & 0.253 \\
Property Management Fee & -0.024 & 0.012 & -1.948 & 0.053 \\
Green Coverage Ratio & 0.016 & 0.020 & 0.823 & 0.411 \\
Elevator & -0.032 & 0.031 & 1.005 & 0.316 \\
Residential Area & -0.001 & 0.024 & -0.429 & 0.668 \\
Floor Area Ratio & -0.054 & 0.023 & -0.041 & 0.968 \\
Building Age & -0.071 & 0.023 & -3.122 & 0.002 \\
\hline
\end{tabular}

Table 9. Variance analysis, urban.

\begin{tabular}{cccccc}
\hline Name & df & SS & MS & F & Significance F \\
\hline Regression Analysis & 9 & 11.335 & 1.259 & 68.296 & $3.085 \mathrm{E}-60$ \\
Residuals & 232 & 4.278 & 0.018 & & \\
Sum & 241 & 15.613 & & \\
\hline
\end{tabular}

\section{Variable "Quality of the Corresponding Public Primary} School" Residual Plot

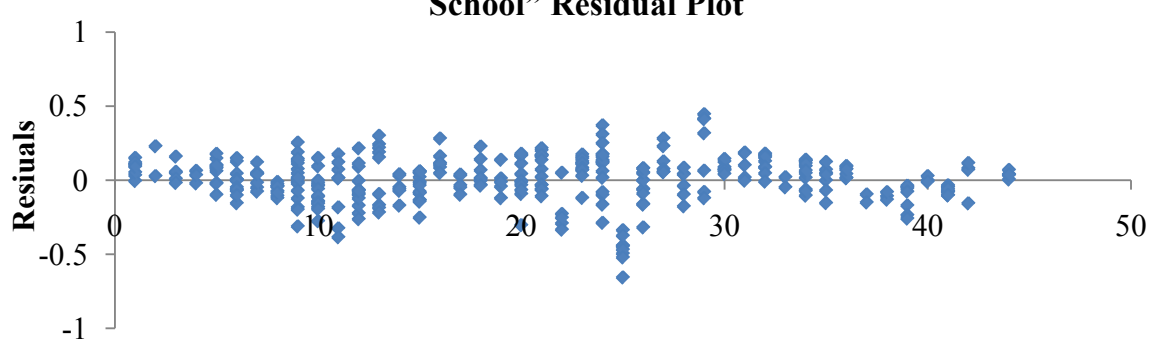

Figure 6. Variable "quality of the corresponding public primary school" residual plot.

\section{Variable "Quality of the Corresponding Public Primary School" Line Fit Plot}

- Housing Price - Housing Price (Expected) — Line Fit (Expected Housing Price)

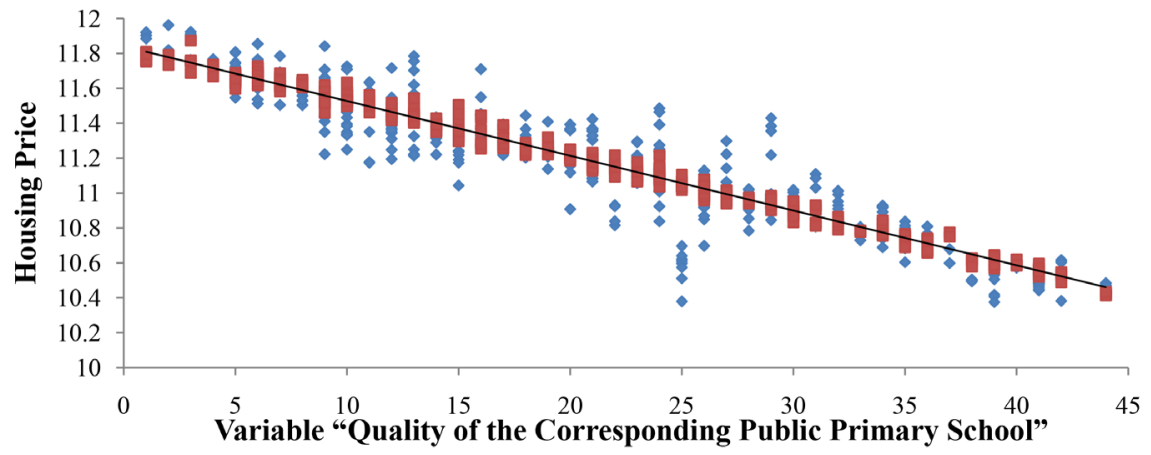

Figure 7. Variable "quality of the corresponding public primary school" line fit plot. 
The results of regression analysis and variance analysis in the suburban areas are given in Table 10 and Table 11, respectively. The variance analysis confirms that the model fits very well with the experimental data and so the coefficients it yielded can be used to explain the sample. The P-values of the coefficients further verify that most of them are statistically significant and fit with their expected signs. Specifically, the coefficient of the quality of the corresponding public primary school is -0.019 , meaning that housing price increases by $1.9 \%$ for a one-rank improvement of its corresponding school (which is equivalent to its numerical rank decreasing by 1 ).

\section{Conclusion}

This paper establishes hedonic regression analysis to investigate the capitalization effect of public school quality into housing prices and quantitatively calculate the exact capitalization rates. Using the data of 344 residential neighborhoods over 7 main districts in Shanghai, it yielded the following empirical results:

1) The quality of the corresponding public primary school has a significant positive effect on housing prices. The compulsory educational facilities are capitalized into estate prices in Shanghai. Under the strict enforcement of the "district correspondence enrollment" policy, families are willing to pay higher prices for houses so that their children can enroll in better schools.

2) The capitalization rate of public school quality is calculated to be $3.1 \%$, $2.8 \%$, and $1.9 \%$ on the citywide, urban, and suburban scales, respectively. When the rank of the corresponding public primary school improves by one, the average housing price in the neighborhood increases by the given percentage.

3) The capitalization effects of public school quality into housing prices exhibit a Matthew Effect, i.e. the amount of capitalization increases rapidly as the quality of the corresponding public primary school approaches the top citywide,

Table 10. Regression analysis, suburban.

\begin{tabular}{ccccc} 
Variable & Coefficient & $\begin{array}{c}\text { Standard } \\
\text { Deviation }\end{array}$ & t Stat & P-value \\
\hline $\begin{array}{c}\text { Intercept } \\
\text { Quality of the Corresponding } \\
\text { Public Primary School } \\
\begin{array}{c}\text { Distance to the Corresponding } \\
\text { Public Primary School }\end{array}\end{array}$ & -0.019 & 0.520 & 20.645 & $2.677 \mathrm{E}-36$ \\
$\begin{array}{c}\text { Distance to the District's CBD } \\
\text { Property Management Fee }\end{array}$ & -0.042 & 0.042 & -6.246 & $1.289 \mathrm{E}-08$ \\
$\begin{array}{c}\text { Green Coverage Ratio } \\
\text { Elevator }\end{array}$ & 0.016 & 0.023 & -2.001 & 0.048 \\
Residential Area & 0.069 & 0.095 & 1.806 & 0.074 \\
Floor Area Ratio & 0.075 & 0.049 & 0.707 & 0.685 \\
Building Age & 0.049 & 0.057 & 0.868 & 0.134 \\
\hline
\end{tabular}


Table 11. Variance Analysis, Suburban.

\begin{tabular}{cccccc}
\hline Name & df & SS & MS & F & Significance F \\
\hline Regression Analysis & 9 & 1.850 & 0.206 & 7.884 & $1.5289 \mathrm{E}-08$ \\
Residuals & 92 & 2.399 & 0.026 & & \\
Sum & 101 & 4.249 & & & \\
\hline
\end{tabular}

Note: When the sample is divided into urban and suburban areas for separate analyses, its size diminishes, so the coefficients of a few variables disagree with their expected signs or have $\mathrm{P}$-value greater than 0.1 . Also, due to the particularity of the designation of school districts and the real estates in Shanghai, many old, unmodern neighborhoods are in close proximity to high-ranking public primary schools near the city center while the neighborhood and structural attributes vary quite erratically especially in suburban areas. Yet the P-value, residual plot, and line fit plot for the school quality variable in all three dimensions are statistically significant and can thus reliably reveal the causational effects and validate the conclusions of this study.

while the effect is much milder for schools at a middle or middle-lower level. Since the increase in housing price is given in percentages, the higher the rank, the more the capitalization effect compounds. On the citywide scale where a larger disparity in school quality is present, the measured capitalization rate is higher than in separate samples. These patterns reflect the serious inequality of access to public educational resources behind the school district housing fever: The gap between low- and high-quality educational resources widened and became even more unaffordable for the low-income families.

\section{Further Implications}

\subsection{Research Significance}

As one of the few existing studies conducted on Shanghai's School District Housing Fever, especially after the strengthening of the "district correspondence enrollment" policy in 2014, this paper examines the status-quo of the local capitalization effect. Most notably, it deals with the lack of sufficient data on public school quality by synthesizing multiple sources. It also samples housing information of 344 neighborhoods in Shanghai and considers seven control variables that account for every aspect in the estate valuation.

Moreover, by using the 2SLS regression method, it avoids the endogeneity bias that has been an issue in most existing researches in the field so that it was able to yield statistically significant results which are also consistent with real-life situations.

\subsection{Policy Recommendations and Action Plans to Mitigate the School District Housing Fever}

The conclusions of this study reveal that the status-quo of the distribution of public educational resources in Shanghai is still considerably unequal. The "district correspondence enrollment" policy itself is a demand-side policy as it regulate the method for enrollment, and so are most of the policies and measures adopted in an attempt to improve China's educational inequality, such as designating common school districts for higher-ranking and lower-ranking schools 
and enroll children in them randomly. Yet as already pointed out in the Literature Review, such policies are predicted to have only a limited effect in mitigating the phenomenon, since although the enrollment mechanism is made to be compulsory, random, or "fair", the gap among the qualities of schools still exists, and the allocation and use of high-quality educational resources would still remain in an unfair advantage to families with better access to other resources, if not even more so.

So at its roots, the School District Housing Fever stems from a critical lack of high-quality public educational resource, and the key to promoting educational equality and cooling down the prices of the private estates also lie in equalizing and improving the qualities of public primary schools. Only in this way can families relieve their anxious competition to get their kids into top-ranking schools by all means.

To achieve this end, the government, the educational institutions, and the society as a whole must all take up specific roles and fulfill their responsibilities. Drawing from the conclusions and real-life experiences, this paper proposes the following recommendations for each party to mitigate the School District Housing Fever and the educational inequality with joint efforts.

Since China's public education is primarily financed and regulated by the government, it should increase its educational input to provide more high-quality educational resources. In fact, this can be done without increasing the tax burden on citizen by instead drawing from higher housing price which arises from the capitalization effect studied in this paper. For those housing estates traded at a price distinctively higher than those of similar estates, a certain proportion of its sales price can be levied as tax (the exact rate of which should be designated based on the amount of capitalization of public school quality in its price). This sum of tax revenue can then be transferred into establishing a Fund for Balancing School District Housing (name only provisional, and the precise working mechanism of such a Fund also requires further discussion in greater detail). Money can then be allocated by the Fund to middle- or lower-quality public institutions in an effort to improve their educational quality. If adopted, this supply-side approach may be able to bridge the gap among the qualities of public schools and enhance educational equality. In preliminary stages, separate Funds can operate with individual districts, while a citywide program can be established as the mechanism matures.

In addition to directly allocate funds to middle- or lower-quality public institutions to improve their educational quality, the government can also work to increase their access to higher-quality educational resources by adopting and promoting programs that involve the exchange and circulation of resource or personnel. By, for example, letting inexperienced teachers and facilitator engage in training programs led by capable teaching staffs from higher-quality institutions, the disparity between educational qualities may also diminish.

But one drawback of these supply-side solutions is that it may take long before they take effect. In the immediate future, one way to increase low-income fami- 
lies' access to high-quality educational resources is to give incentive to public schools. For example, a certain amount of monetary reward can be given for the school to enroll one pupil from humble family backgrounds, and the funding may as well come from the Fund collected from the feverish housing prices. This measure may propel the schools to take initiatives towards educational inequality on their parts. Also, in the housing market regulation process, the important role of public goods layout and urban planning policy should also be emphasized so that the workings of the real estate market does not interfere with or exacerbate the School District Housing Fever.

When it comes to public educational institutions, they should take a proactive part in enhancing and equalizing educational qualities among themselves. This can be done by encouraging the exchange and circulation of resources on the school level and seeking the support from local governments. Several schools, including higher- and lower-quality ones, in Changning District has already been engaging in such an initiative: Teachers and staff that participate in cross-school exchange and training programs are prioritized in promotions of their professional titles and are given extra bonuses. Being advocated by the district's Educational Bureau, this program is expanding its scale to involve more participant schools.

The responsibility of the society as a whole is to facilitate the circulation of information and give support to the improvement and equalization of the educational qualities. One way to do this is by volunteering in programs and initiatives that trains teachers and facilitator, especially for lower-quality institutions. Another way for private entities to mitigate the fierce competition of high-quality public schools is to allocate more social capital in establishing private educational institutions, so that higher-income families may have more choices and the excess demand for public institutions can be balanced. Lastly, average families, homebuyers and investors should refrain from speculative purchases of school district housing that exacerbates their feverish prices and makes them even more inaccessible to low-income families.

\section{Conflicts of Interest}

The authors declare no conflicts of interest regarding the publication of this paper.

\section{References}

Aitkin, M., \& Longford, N. (1986). Statistical Modeling Issues in School Effectiveness Studies (with Discussion). Journal of the Royal Statistical Society, (A)149, 1-43.

Black, S. (1999). Do Better Schools Matter? Parental Valuation of Elementary Education. The Quarterly Journal of Economics, 114, 577-599. https://doi.org/10.1162/003355399556070

Boardman, A., \& Murnane, R. (1979). Using Panel Data to Improve Estimates of the Determinants of Educational Achievement. Sociology of Education, 52, 113-121. https://doi.org/10.2307/2112449 
Brasington, D. (2006). Educational Outcomes and House Values: A Test of the Value Added Approach. Journal of Regional Science, 46, 245-268. https://doi.org/10.1111/j.0022-4146.2006.00440.x

Dills, A. (2004). Do Parents Value Changes in Test Scores? High Stakes Testing inTexas. Contributions to Economic Analysis and Policy, 3, Article 10.

Downes, T., \& Zabel, J. E. (2002). The Impact of School Characteristics on House Prices: Chicago 1987-1991. Journal of Urban Economics, 52, 1-25. https://doi.org/10.1016/S0094-1190(02)00010-4

Dubin, R., \& Goodman, A. (1982). Valuation of Education and Crime Neighborhood: Characteristics through Hedonic Housing Prices. Population and Environment, 5, 166. https://doi.org/10.1007/BF01257055

Fang (2017). Fangtianxia Company Profile. http://www.fang.com/aboutus/aboutus.html

Feng, H., \& Lu, M. (2010). School Quality and Housing Prices: Empirical Evidence from a Natural Experiment in Shanghai, China. Journal of Housing Economics, 22, 291-307. https://doi.org/10.1016/j.jhe.2013.10.003

General Office of the Ministry of Education of People's Republic of China (2014). Notice on Further Improving the District Correspondence Enrollment of Compulsory Education in Major Large Cities. Beijing: General Office of the Ministry of Education of People's Republic of China.

Hanushek, E., Rivkin, S., \& Taylor, L. (1996). The Identification of School Resource Effects. Education Economics, 4, 105-125. https://doi.org/10.1080/09645299600000012

Hatong Shanghai Shengxue (2017). On Hatong’s Research \& Study Programs. https://mp.weixin.qq.com/s/CE6FpY237n8O7GiWUZHfsA?

Haurin, D., \& Brasington, D. (1996). School Quality and Real House Prices: Inter-and Intrametropolitan Effects. Journal of Housing Economics, 5, 351-368. https://doi.org/10.1006/jhec.1996.0018

Hayes, K. J., \& Taylor, L. L. (1996). Neighborhood School Characteristics: What Signals Quality to Homebuyers? Federal Reserve Bank of Dollas Economic Review, 3, 2-9.

Hu, Y., \& Yinger, J. (2008). The Impact of School District Consolidation on Housing Prices. National Tax Journal, 61, 4. https://doi.org/10.17310/ntj.2008.4.03

Huang, B. (2010). The Effect of Middle School Qualities on the Price of Surrounding Houses: Using Beilin District in Xi'an Province as an Example. Business China, 3, 164-166.

Lianjia (2017a). Prices for Current Sales of Houses in Quandong Neighborhood. http://sh.lianjia.com/ershoufang/rs\%E6\%B3\%89\%E4\%B8\%9C\%E5\%B0\%8F\%E5\%8C\% BA

Lianjia (2017b). Prices for Current Sales of Houses in Weifang No.2 Neighborhood. http://sh.lianjia.com/ershoufang/rs\%E6\%BD\%8D\%E5\%9D\%8A\%E4\%BA\%8C\%E6\%9 $\underline{\mathrm{D} \% 91}$

Liu, R., \& Sun, X. (2015). The Effect of Education Quality Capitalization on Housing Prices Based on Empirical Analysis of Elementary School District of Wuhou District in Chengdu. Finance and Economics, 8, 91-99.

Liu, Y., \& Yi, S. (2011). Capitalization of Public Goods and Its Distribution Effect: Empirical Evidences and Policy Implications in China. International Journal of Business Administration, 2, 38-43. https://doi.org/10.5430/ijba.v2n1p38

Mao, F., Luo, G., \& Pan, J. (2014). The Effect of Elementary Education on the Price of Hangzhou School District Housing, Urban and Environmental Studies, 2, 53-64. 
Meng, Y., \& Jia, S. (2014). Impact of Primary School Qualities on Price of School District Housing in Guangzhou. Journal of Engineering Management, 3, 133-137.

Ministry of Education of People's Republic of China (2014a). Opinions on Further Implementing the Examination-Free Entrance from Primary School to Middle School by Proximity. old.moe.gov.cn//publicfiles/business/htmlfiles/moe/s3321/201401/163246.html

Ministry of Education of People's Republic of China (2014b). Opinions on the Implementation of Further Improving the District Correspondence Enrollment into Junior Middle Schools. Beijing: Ministry of Education of People's Republic of China.

Monson, M. (2009). Valuation Using Hedonic Pricing Models. Cornell Real Estate Review, 7, 62-73.

National Data (2018). 2009-2013 China's Industrial Growth and Secondhand Housing Sales Volume Growth Data.

http://data.stats.gov.cn/search.htm?s=\%E6\%88\%BF\%E5\%9C\%B0\%E4\%BA\%A7\%E8\% A1\%8C\%E4\%B8\%9A\%E5\%A2\%9E\%E9\%95\%BF

Nguyen-Hoang, P., \& Yinger, J. (2011). The Capitalization of School Quality into House Values: A Review. Journal of Housing Economics, 20, 30-48.

https://doi.org/10.1016/j.jhe.2011.02.001

Oates, W. (1969). The Effects of Property Taxes and Local Public Spending on Property Values: An Empirical Study of Tax Capitalization and the Tiebout Hypothesis. Journal of Political Economy, 77, 957-961. https://doi.org/10.1086/259584

Rosen, H., \& Fullerton D. J. (1977). A Note on Local Tax Rates, Public Benefit Levels, and Property Values. Journal of Political Economy, 85, 433-440. https://doi.org/10.1086/260575

Shanghai Education Commission (2016). Opinions on the Implementation of the Enrollment Practices of Compulsory Educational Institutions. Shanghai: Shanghai Education Commission.

Sixth National People's Congress (1986). The Law of Compulsory Education of People's Republic of China (Ninth Article).

The State Council (2012). Several Opinions on Further Promoting the Balanced Development of Compulsory Education. Beijing: The State Council.

Tiebout, C. (1956). A Pure Theory of Local Expenditures. Journal of Political Economy, 64, 416-424. https://doi.org/10.1086/257839

Wang, X., Ge, Y., \& Zhang, H. (2010). Research on the Price Mechanism of School District Housing in Nanjing Old Area. CO-Operative Economy \& Science, 12, 10-13.

Wen, H., \& Tao, Y. (2015). Polycentric Urban Structure and Housing Price in the Transitional China: Evidence from Hangzhou. Habitat International, 46, 138-146.

Wen, H., Yang, S., \& Qin, Z. (2013). The Impact of Educational Facilities on Housing Price: An Empirical Analysis on the Prospective of the Capitalization for Public Goods. China Land Science, 1, 34-40.

Wen, H., Zhang, Y., \& Zhang, L. (2014). Do Educational Facilities Affect Housing Price? An Empirical Study in Hangzhou, China. Habitat International, 42, 155-163.

Wen, Y., \& Chen, K. (2014). The Great Housing Boom of China. FRB of St. Louis Working Paper No. 2014-022A.

Xingdd (2016). 2016 Big Data Research Report on School District Housing in Shanghai. http://www.xingdd.com/report_2016.html

Zou, D. (2008). Blue Book of Development and Reform. Beijing: Social Sciences Academic Press (China). 


\section{Appendix}

(a)

\begin{tabular}{|c|c|c|c|c|c|}
\hline Neighborhood & Housing Price & $\begin{array}{l}\text { Quality of the Corresponding } \\
\text { Public Primary School }\end{array}$ & $\begin{array}{l}\text { Distance to the } \\
\text { Corresponding Public } \\
\text { Primary School }\end{array}$ & $\begin{array}{l}\text { Distance to the } \\
\text { District's CBD }\end{array}$ & $\begin{array}{c}\text { Property } \\
\text { Management Fee }\end{array}$ \\
\hline $\begin{array}{l}\text { Huarun Waitan Jiuli } \\
\text { Neighborhood }\end{array}$ & 131,224 & 13 & 127 & 4500 & 7.7 \\
\hline Haiqi Garden & 120,840 & 13 & 110 & 4300 & 2.4 \\
\hline Shanghaitan Garden & 127,307 & 13 & 260 & 4100 & 1.5 \\
\hline Changfeng Garden & 111,397 & 13 & 874 & 4500 & 2 \\
\hline Yuelai Neighborhood & 105,714 & 13 & 308 & 4100 & 0.7 \\
\hline Yangguan Cuizu Garden & 82,905 & 13 & 1000 & 4300 & 1.7 \\
\hline $\begin{array}{l}\text { Yangguanli/Yangguan } \\
\text { Neighborhood }\end{array}$ & 76,859 & 13 & 940 & 4500 & 1.7 \\
\hline Xueshui Garden & 74,137 & 13 & 930 & 5100 & 1.3 \\
\hline Fuxin Building & 74,766 & 13 & 240 & 4300 & 1.35 \\
\hline Shilin Hua Garden & 93,661 & 16 & 440 & 3500 & 2 \\
\hline Sinan Mansion & 121,720 & 16 & 470 & 3300 & 5 \\
\hline Yandang Building & 94,202 & 16 & 1100 & 1700 & 1 \\
\hline Xiangshan Lishe Apartment & 103,684 & 16 & 300 & 2600 & 5 \\
\hline Ruixue Building & 86,666 & 16 & 1100 & 3900 & 0.5 \\
\hline Road Shangxi Nan, Lane 271 & 83,181 & 16 & 1100 & 3800 & 0.5 \\
\hline Yongye Apartment & 122,516 & 12 & 460 & 3500 & 2.22 \\
\hline Huilong Apartment & 102,953 & 12 & 910 & 3500 & 2.25 \\
\hline Shunfeng Apartment & 103,448 & 12 & 700 & 3200 & 0.8 \\
\hline Taoyuanxin Garden & 92,813 & 12 & 970 & 3800 & 1.5 \\
\hline Baihui Building & 88,147 & 12 & 600 & 3500 & 2 \\
\hline Mengxi Neighborhood & 72,727 & 12 & 760 & 3100 & 0.6 \\
\hline Singapore Garden & 88,611 & 12 & 340 & 2600 & 2.45 \\
\hline Fuxingjia Garden & 86,727 & 12 & 510 & 4500 & 1.6 \\
\hline Yuntai Apartment & 84,445 & 12 & 40 & 3700 & 1.48 \\
\hline Yinxin Garden & 81,699 & 12 & 1100 & 4100 & 1.5 \\
\hline Beimengsan Neighborhood & 85,000 & 12 & 690 & 3200 & 0.5 \\
\hline Lili Neighborhood & 86,000 & 12 & 560 & 4000 & 0.8 \\
\hline Chengshen Apartment & 76,691 & 12 & 70 & 3900 & 1.5 \\
\hline Yaojiang Garden & 138,924 & 9 & 320 & 4600 & 2.5 \\
\hline Nankang Apartment & 109,272 & 9 & 1400 & 5000 & 1.6 \\
\hline Zhongnan Neighborhood & 103,269 & 9 & 1000 & 4400 & 1.2 \\
\hline Huixiang Apartment & 101,369 & 9 & 1500 & 5100 & 1.5 \\
\hline Jinzhong Garden & 102,352 & 9 & 700 & 4700 & 2 \\
\hline
\end{tabular}




\section{Continued}

\begin{tabular}{|c|c|c|c|c|c|}
\hline Shimin Neighborhood & 106,090 & 9 & 1300 & 4600 & 0.35 \\
\hline Honghui Neighborhood & 90,322 & 9 & 1300 & 4000 & 1.8 \\
\hline Jianle Neighborhood & 121,422 & 9 & 920 & 2100 & 1 \\
\hline Danshuiwan Garden & 112,403 & 9 & 930 & 3200 & 3.5 \\
\hline Jiande Neighborhood & 116,060 & 9 & 1600 & 2600 & 1.35 \\
\hline Madang Neighborhood & 115,263 & 9 & 920 & 2100 & 1.1 \\
\hline Danshui Apartment & 92,347 & 9 & 40 & 2500 & 1.6 \\
\hline Bashi Neighborhood & 104,586 & 9 & 100 & 2700 & 0.85 \\
\hline Fuxing Neighborhood & 84,913 & 9 & 860 & 2500 & 2 \\
\hline Ruijin garden & 74,777 & 9 & 610 & 2800 & 1 \\
\hline Changjiang Apartment & 156,666 & 2 & 610 & 1700 & 2 \\
\hline Huasheng Mansion & 135,771 & 2 & 640 & 1300 & 2.8 \\
\hline East Huihai Apartment & 104,761 & 9 & 1200 & 2500 & 1.8 \\
\hline Taoyuan Neighborhood & 93,421 & 9 & 770 & 2400 & 0.6 \\
\hline $\begin{array}{c}\text { Zhongfu Huayuan Yong } \\
\text { Apartment }\end{array}$ & 134,411 & 5 & 1300 & 4700 & 1.8 \\
\hline Haichao Neighborhood & 133,757 & 5 & 950 & 4300 & 1.2 \\
\hline Road Haichao, Lane 256 & 120,000 & 5 & 1100 & 4400 & 1.2 \\
\hline Nanpu Apartment & 123,529 & 5 & 1100 & 4700 & 1.2 \\
\hline Renbao Apartment & 126,470 & 5 & 990 & 4300 & 1.8 \\
\hline Baihui Apartment & 125,728 & 5 & 1300 & 4700 & 1.2 \\
\hline Jinri Shijia Neighborhood & 116,893 & 5 & 630 & 4000 & 1.9 \\
\hline Haizhou Guoji Garden & 115,664 & 5 & 790 & 4300 & 2 \\
\hline Tianzhushan Neighborhood & 103,333 & 5 & 910 & 4400 & 1.2 \\
\hline Quxi Village & 120,416 & 5 & 910 & 4300 & 0.6 \\
\hline Liyuan Village & 93,333 & 18 & 940 & 4000 & 0.6 \\
\hline Yilv Apartment & 86,425 & 18 & 1000 & 4100 & 0.5 \\
\hline Dingda Apartment & 83,293 & 18 & 970 & 4100 & 0.61 \\
\hline Dongyu Garden & 78,070 & 18 & 1300 & 4800 & 2 \\
\hline Santana Building & 74,358 & 18 & 1100 & 4200 & 1.5 \\
\hline Road Mengzi, Lane 395 & 74,444 & 18 & 390 & 4000 & 0.35 \\
\hline New Jiangnan Shiji Garden & 81,000 & 18 & 290 & 4300 & 1.7 \\
\hline Daxin Building & 73,333 & 18 & 520 & 4100 & 0.6 \\
\hline Jiayuting & 150,621 & 3 & 353 & 1300 & 14.8 \\
\hline Shijia Neighborhood & 148,631 & 3 & 135 & 1100 & 0.6 \\
\hline Road Jiashan, Lane 232 & 125,931 & 3 & 660 & 1300 & 0.5 \\
\hline Wutong Garden & 128,314 & 3 & 540 & 1500 & 2.2 \\
\hline Dingxin Building & 125,696 & 3 & 710 & 1700 & 4 \\
\hline
\end{tabular}




\section{Continued}

\begin{tabular}{|c|c|c|c|c|c|}
\hline $\begin{array}{c}\text { Oriental Manhattan, } \\
\text { Shangdong Neighborhood }\end{array}$ & 140,686 & 6 & 470 & 670 & 8 \\
\hline Zhongyuan Village & 128,681 & 6 & 570 & 1500 & 0.8 \\
\hline Wending Tianxia Garden & 122,502 & 6 & 430 & 1600 & 2.56 \\
\hline Taide Garden & 119,617 & 6 & 270 & 1300 & 2.8 \\
\hline Road Yude, Lane 66 & 112,738 & 6 & 520 & 1600 & 0.8 \\
\hline Oriental Manhattan & 118,916 & 6 & 450 & 930 & 3.35 \\
\hline Jinghui Garden & 113,967 & 6 & 70 & 1300 & 1.6 \\
\hline Yifeng Garden & 112,032 & 6 & 310 & 1200 & 2 \\
\hline Road Xuhong, Lane 110 & 110,762 & 6 & 640 & 850 & 0.8 \\
\hline Shiye Apartment & 108,910 & 6 & 910 & 510 & 2.5 \\
\hline Taide Hua Garden & 99,888 & 6 & 370 & 1700 & 2.5 \\
\hline Kaixuan Haoting & 110,525 & 6 & 500 & 1800 & 2.8 \\
\hline Kaihua Apartment & 102,410 & 6 & 730 & 2000 & 2 \\
\hline Road Kangping, Lane 207 & 147,585 & 1 & 850 & 800 & 0.5 \\
\hline Gong'an Building & 131,474 & 1 & 750 & 1400 & 0.5 \\
\hline Tianping Neighborhood & 130,731 & 1 & 1200 & 730 & 1.3 \\
\hline Jingfu Garden & 149,981 & 1 & 1000 & 1100 & 2.4 \\
\hline Road Gao'an, Lane 9 & 147,834 & 1 & 110 & 1700 & 0.5 \\
\hline Road Henshang, Lane 696 & 134,723 & 1 & 840 & 1100 & 0.8 \\
\hline Huaqiang Apartment & 150,370 & 1 & 440 & 1400 & 1.4 \\
\hline Wuxing Apartment & 145,044 & 1 & 550 & 1400 & 1.2 \\
\hline Yi Garden & 97,916 & 10 & 240 & 1900 & 1.5 \\
\hline Yueyang Building & 95,117 & 10 & 50 & 2100 & 1.2 \\
\hline Road Yueyang, Lane 200 & 99,686 & 10 & 140 & 2200 & 0.5 \\
\hline Baroque Palace & 92,271 & 10 & 320 & 1800 & 6.5 \\
\hline Gaoxing Apartment & 84,883 & 10 & 560 & 1800 & 2 \\
\hline Zhongkai Chengshi Zhiguang & 123,789 & 10 & 300 & 1500 & 6 \\
\hline Dongfang Shikong Apartment & 121,656 & 10 & 380 & 900 & 2.2 \\
\hline Hongqiao Leting Pojin & 101,881 & 10 & 240 & 1100 & 2.3 \\
\hline Nandan Neighborhood & 100,189 & 10 & 460 & 770 & 0.76 \\
\hline Minghui Garden & 95,367 & 10 & 600 & 1400 & 1.2 \\
\hline Kaixuan $1^{\text {st }}$ village & 88,924 & 10 & 350 & 1500 & 0.6 \\
\hline Fannan Neighborhood & 87,928 & 10 & 190 & 1300 & 0.8 \\
\hline Nanyi Garden & 83,930 & 10 & 720 & 1300 & 1.45 \\
\hline Yanggang Mansion & 83,459 & 10 & 650 & 1700 & 2.2 \\
\hline Jiaoda Apartment & 76,751 & 10 & 430 & 930 & 1.1 \\
\hline
\end{tabular}




\section{Continued}

\begin{tabular}{|c|c|c|c|c|c|}
\hline Dongfang Paris Garden & 122,221 & 4 & 330 & 3500 & 3.8 \\
\hline Yongtai Neighborhood & 124,308 & 4 & 740 & 2800 & 0.6 \\
\hline Mingyuan Shiji City & 128,909 & 4 & 310 & 3200 & 2.2 \\
\hline Baoli Xi'an & 90,765 & 15 & 570 & 3300 & 7 \\
\hline Haibo Xuhui Fudi & 99,195 & 15 & 1000 & 3600 & 6 \\
\hline Shanghaiwan Haoting & 88,000 & 15 & 1200 & 3900 & 4 \\
\hline Linjiang Haoyuan & 96,018 & 15 & 70 & 2700 & 2.2 \\
\hline Xuhui Garden & 90,538 & 15 & 1600 & 2800 & 2.8 \\
\hline Shuangfeng Neighborhood & 89,416 & 15 & 760 & 3000 & 0.8 \\
\hline Shenhang Neighborhood & 86,899 & 15 & 1500 & 2600 & 0.8 \\
\hline Wannan fifth Village & 79,960 & 15 & 730 & 3200 & 0.6 \\
\hline Xiechang Neighborhood & 76,274 & 15 & 1200 & 2400 & 1 \\
\hline Wannan sixth Village & 75,761 & 15 & 1200 & 2500 & 0.8 \\
\hline Dong'an Garden & 74,392 & 15 & 810 & 3200 & 1.5 \\
\hline Huarong Neighborhood & 72,448 & 15 & 640 & 3100 & 0.5 \\
\hline Meike Apartment & 71,225 & 15 & 990 & 1900 & 0.6 \\
\hline Dongan fourth Village & 82,096 & 15 & 420 & 2400 & 0.6 \\
\hline Dong'an $2^{\text {nd }}$ Village & 62,500 & 15 & 1100 & 3000 & 0.6 \\
\hline Shuxiang Yiju & 92,410 & 14 & 640 & 7700 & 1.35 \\
\hline $\begin{array}{l}\text { Shanghai Middle School } \\
\text { Neighborhood }\end{array}$ & 88,823 & 14 & 1200 & 2900 & 0.6 \\
\hline Xinluo Garden & 87,522 & 14 & 530 & 2400 & 2 \\
\hline Changqiao $5^{\text {th }}$ Village & 81,990 & 14 & 190 & 2400 & 0.5 \\
\hline Guanghua Garden & 79,960 & 14 & 980 & 2600 & 0.6 \\
\hline Changqiao $1^{\text {st }}$ Village & 74,607 & 14 & 330 & 2700 & 1 \\
\hline Zhonghong Huizhiyuan & 91,473 & 21 & 520 & 220 & 1.7 \\
\hline Kehui Jingyuan & 86,665 & 21 & 580 & 1200 & 1.5 \\
\hline Zhonghai Xinyuan & 85,775 & 21 & 910 & 1100 & 2.5 \\
\hline Hebin Guoji Apartment & 81,130 & 21 & 480 & 570 & 2.15 \\
\hline Mingjia Garden & 86,435 & 21 & 1500 & 2000 & 1.3 \\
\hline Caoxi $3^{\text {rd }}$ Village & 85,317 & 21 & 90 & 800 & 0.6 \\
\hline Xuejiazhai & 83,237 & 21 & 330 & 1000 & 0.35 \\
\hline Zishuyuan & 83,099 & 21 & 620 & 760 & 1.55 \\
\hline Road Qinzhou, Lane 111 & 69,957 & 21 & 700 & 840 & 1.8 \\
\hline Road Longwu, Lane 11 & 69,541 & 21 & 1100 & 1700 & 0.5 \\
\hline Xuhui Apartment & 69,352 & 21 & 1200 & 990 & 1.5 \\
\hline Huafu Apartment & 65,221 & 21 & 970 & 1600 & 1.4 \\
\hline Caoxi $1^{\text {st }}$ Village & 65,010 & 21 & 590 & 1000 & 0.8 \\
\hline
\end{tabular}




\section{Continued}

\begin{tabular}{|c|c|c|c|c|c|}
\hline Longcao Building & 63,947 & 21 & 800 & 420 & 1.2 \\
\hline Aijian Garden & 67,945 & 26 & 750 & 1100 & 2 \\
\hline Tianlin $11^{\text {th }}$ Village & 60,576 & 26 & 310 & 1200 & 1.2 \\
\hline Kehua Apartment & 60,057 & 26 & 750 & 170 & 1.8 \\
\hline Tianlin $12^{\text {th }}$ Village & 59,004 & 26 & 290 & 620 & 0.7 \\
\hline Yibiao Xin Village & 55,118 & 26 & 1300 & 760 & 0.6 \\
\hline Tianlin $14^{\text {th }}$ Village & 51,510 & 26 & 510 & 1500 & 1.2 \\
\hline Huading Guangchang & 44,235 & 26 & 1200 & 1700 & 1.2 \\
\hline Tianlin Tiyu Apartment & 52,530 & 26 & 690 & 830 & 1.2 \\
\hline Qinzhou Aparment & 59,530 & 26 & 370 & 1000 & 0.3 \\
\hline Fuyuan Neighborhood & 68,125 & 26 & 50 & 1100 & 1.2 \\
\hline Tianlin Xin Garden & 66,666 & 26 & 590 & 1000 & 1.45 \\
\hline QinzhouXin Garden & 57,057 & 26 & 210 & 1300 & 0.8 \\
\hline Tianran Ju & 80,683 & 27 & 790 & 2200 & 1.98 \\
\hline Yuannan $3^{\text {rd }}$ Village & 74,783 & 27 & 460 & 1800 & 1 \\
\hline Yuannan 1st Village & 69,035 & 27 & 190 & 1600 & 1.3 \\
\hline Yuannan $2^{\text {nd }}$ Village & 63,789 & 27 & 110 & 1800 & 0.6 \\
\hline Bailong Neighborhood & 61,443 & 27 & 1300 & 2700 & 0.8 \\
\hline Zhongheng Garden & 59,557 & 27 & 1300 & 3000 & 0.45 \\
\hline Haishang Huating & 80,445 & 23 & 1000 & 900 & 1.85 \\
\hline Changqing Fan & 80,074 & 23 & 220 & 1800 & 0.5 \\
\hline Zijin Garden & 74,242 & 23 & 1300 & 2000 & 1 \\
\hline Changxin Garden & 74,166 & 23 & 930 & 1900 & 0.5 \\
\hline Shouyi Fang & 73,519 & 23 & 530 & 1400 & 0.5 \\
\hline Wanxiang Garden & 71,923 & 23 & 1800 & 2500 & 0.6 \\
\hline Chahua Garden & 71,892 & 23 & 740 & 1200 & 1.4 \\
\hline Road Weat Guilin, Lane 101 & 71,310 & 23 & 910 & 2500 & 0.8 \\
\hline Changfeng Fang & 70,986 & 23 & 270 & 1700 & 0.5 \\
\hline Guiping Neighborhood & 65,812 & 23 & 1900 & 990 & 0.65 \\
\hline Changhong Fang & 63,355 & 23 & 60 & 2100 & 1.3 \\
\hline Lan Ting & 131,272 & 7 & 1400 & 1300 & 14.3 \\
\hline Jiali Huating & 113,029 & 7 & 220 & 450 & 5.5 \\
\hline Dingxiang Apartment & 116,972 & 7 & 390 & 940 & 1.8 \\
\hline Jianghua Jidian Building & 114,732 & 7 & 500 & 420 & 1 \\
\hline Dongfang Yayuan & 119,546 & 7 & 290 & 840 & 3 \\
\hline Xinhai Neighborhood & 99,129 & 7 & 510 & 360 & 0.85 \\
\hline Yanwu Jidian Building & 108,652 & 7 & 620 & 230 & 1.2 \\
\hline
\end{tabular}




\section{Continued}

\begin{tabular}{|c|c|c|c|c|c|}
\hline Jiaxin Chengshi Apartment & 118,085 & 7 & 810 & 540 & 1.8 \\
\hline Qishan Village & 113,122 & 11 & 490 & 1300 & 0.8 \\
\hline Yuyuan Mansion & 112,618 & 11 & 240 & 1200 & 2.8 \\
\hline Nanhui Neighborhood & 107,280 & 11 & 280 & 1400 & 0.28 \\
\hline Road Xuanhua, Lane 268 & 102,733 & 11 & 110 & 990 & 1.2 \\
\hline Xuanhua Neighborhood & 99,940 & 11 & 250 & 1300 & 0.8 \\
\hline Fu'an Neighborhood & 85,068 & 11 & 40 & 1100 & 0.8 \\
\hline Haixin Huayuan & 71,524 & 11 & 330 & 1000 & 1.5 \\
\hline Zhongbao Apartment & 71,174 & 11 & 210 & 1400 & 5 \\
\hline Gubei Guoji Garden & 110,922 & 8 & 580 & 1700 & 3.85 \\
\hline Gubei Zhongyang Garden & 104,678 & 8 & 1000 & 1200 & 3.45 \\
\hline Yucui Haoting & 104,400 & 8 & 780 & 1900 & 4.5 \\
\hline Gubei Ruishi Garden & 101,460 & 8 & 630 & 1600 & 4.8 \\
\hline Jinse Beilawei & 109,943 & 8 & 460 & 2200 & 3.65 \\
\hline Hualijiazu Gubei Garden & 109,885 & 8 & 250 & 2000 & 3.95 \\
\hline Gubei Guoji Plaza & 106,773 & 8 & 760 & 1500 & 3.35 \\
\hline Qiangsheng Gubei Garden & 99,059 & 8 & 600 & 2100 & 3.8 \\
\hline Gubei Jianian Garden & 101,825 & 8 & 1000 & 1100 & 3.2 \\
\hline Raofeng Jiayuan & 97,241 & 24 & 900 & 220 & 2.5 \\
\hline Changxin Neighborhood & 88,569 & 24 & 320 & 1100 & 0.6 \\
\hline Jinyang Neighborhood & 77,005 & 24 & 70 & 1000 & 1.2 \\
\hline $\begin{array}{c}\text { Liyuan Kaixuan } \\
\text { Neighborhood }\end{array}$ & 76,205 & 24 & 1300 & 650 & 0.9 \\
\hline Wanhua Neighborhood & 76,043 & 24 & 610 & 1100 & 0.8 \\
\hline Huayuancun Yayuan & 75,845 & 24 & 430 & 1200 & 1.8 \\
\hline Huaxin Neighborhood & 73,159 & 24 & 490 & 1400 & 1 \\
\hline Daming Neighborhood & 71,001 & 24 & 550 & 1300 & 0.5 \\
\hline Wanhang Neighborhood & 68,519 & 24 & 770 & 1700 & 1.2 \\
\hline Xinglian Building & 60,379 & 24 & 230 & 960 & 0.6 \\
\hline Zhaofeng Garden & 50,933 & 24 & 320 & 1300 & 2.9 \\
\hline Changning 88 Jinting & 95,279 & 24 & 120 & 160 & 3.3 \\
\hline Changjiang Neighborhood & 78,831 & 24 & 410 & 280 & 1.2 \\
\hline Road Changning, Lane 234 & 70,715 & 24 & 30 & 210 & 0.82 \\
\hline Yinxin Neighborhood & 60,747 & 24 & 380 & 270 & 0.8 \\
\hline Daqiao Neighborhood & 55,462 & 24 & 220 & 70 & 0.5 \\
\hline Hongqiao Haoyuan & 92,043 & 29 & 740 & 880 & 4.95 \\
\hline Tianshan $2^{\text {nd }}$ Village & 87,858 & 29 & 30 & 170 & 0.6 \\
\hline Cuiting & 85,420 & 29 & 560 & 540 & 0.9 \\
\hline
\end{tabular}




\section{Continued}

\begin{tabular}{|c|c|c|c|c|c|}
\hline Zhongzi Neighborhood & 74,451 & 29 & 640 & 780 & 0.6 \\
\hline Ziyu Building & 59,632 & 29 & 690 & 830 & 1.1 \\
\hline Jingming Building & 53,801 & 29 & 880 & 1000 & 11.4 \\
\hline Xinshiji Plaza & 51,263 & 29 & 590 & 580 & 5.7 \\
\hline Renheng Hebin Garden & 90,164 & 19 & 1200 & 1200 & 4 \\
\hline Gusong Neighborhood & 78,930 & 19 & 10 & 1400 & 0.7 \\
\hline Shuixia Neighborhood & 76,857 & 19 & 150 & 1300 & 0.58 \\
\hline Xinxia Neighborhood & 73,691 & 19 & 750 & 1900 & 1.01 \\
\hline Maotai Yayuan & 68,702 & 19 & 240 & 1400 & 1.25 \\
\hline Chang Yuan & 88,668 & 17 & 340 & 1500 & 5 \\
\hline Wangzui Jinpin & 83,990 & 17 & 530 & 1100 & 8 \\
\hline Beiwang Neighborhood & 80,298 & 17 & 790 & 1300 & 0.5 \\
\hline $\begin{array}{l}\text { Road West Yanan, Lane } \\
\qquad 548 / 60\end{array}$ & 76,496 & 17 & 620 & 1200 & 0.6 \\
\hline Huaming Shiji Plaza & 74,400 & 17 & 880 & 1300 & 2.5 \\
\hline Dangdai Xinhua & 88,639 & 20 & 860 & 460 & 2 \\
\hline Tiandu Neighborhood & 85,858 & 20 & 750 & 360 & 0.6 \\
\hline Donghu Mingyuan & 85,806 & 20 & 700 & 530 & 2 \\
\hline Yangzha Neighborhood & 76,776 & 20 & 530 & 500 & 0.8 \\
\hline Xinhua Apartment & 73,032 & 20 & 820 & 660 & 1.5 \\
\hline Huaqian Apartment & 72,775 & 20 & 750 & 360 & 0.8 \\
\hline Huagong Apartment & 71,205 & 20 & 330 & 300 & 0.8 \\
\hline Xinhua Garden & 70,028 & 20 & 750 & 360 & 5 \\
\hline Road Fahuazhen, Lane 878 & 67,340 & 20 & 640 & 480 & 0.6 \\
\hline Pujiang Building & 54,616 & 20 & 780 & 620 & 1.6 \\
\hline Taoan Neighborhood & 86,557 & 20 & 590 & 760 & 0.6 \\
\hline Xinshidai Jingting & 72,060 & 22 & 1300 & 1900 & 0.8 \\
\hline Tongji Huacheng & 55,868 & 22 & 1000 & 3000 & 1.5 \\
\hline Hejia Apartment & 55,497 & 22 & 60 & 2100 & 1 \\
\hline Weilan Chengshi Garden & 49,775 & 22 & 1700 & 2200 & 1.7 \\
\hline Huamei Garden & 50,956 & 22 & 1400 & 2900 & 0.43 \\
\hline Yuxing Garden & 60,924 & 28 & 620 & 1700 & 1.35 \\
\hline Shengsong $8^{\text {th }}$ Village & 59,354 & 28 & 320 & 2300 & 0.5 \\
\hline Shengsong $9^{\text {th }}$ Village & 61,310 & 28 & 600 & 1600 & 0.55 \\
\hline Shengsong $5^{\text {th }}$ Village & 54,381 & 28 & 500 & 2500 & 0.8 \\
\hline Shengsong 3rd Village & 51,739 & 28 & 220 & 2200 & 0.5 \\
\hline Dongyuan Jindu Garden & 48,249 & 28 & 650 & 1700 & 0.85 \\
\hline Huangdu Garden & 40,992 & 25 & 2100 & 2900 & 3.5 \\
\hline
\end{tabular}




\section{Continued}

\begin{tabular}{|c|c|c|c|c|c|}
\hline Dongfang Garden & 40,953 & 25 & 1600 & 1800 & 1.8 \\
\hline Puhui Xincheng & 40,005 & 25 & 780 & 240 & 0.6 \\
\hline Xiangge Liyuan & 40,509 & 25 & 280 & 1100 & 1.5 \\
\hline Puhui Apartment & 39,134 & 25 & 730 & 270 & 0.44 \\
\hline Xueyuan Xin Village & 44,204 & 25 & 770 & 1600 & 0.6 \\
\hline Baorong Xin Village & 41,799 & 25 & 990 & 570 & 0.4 \\
\hline Xiufeng Cuigu & 36,733 & 25 & 1400 & 1300 & 1.25 \\
\hline Jintai Apartment & 32,184 & 25 & 940 & 810 & 0.8 \\
\hline Xin Shenhua Moli Garden & 60,242 & 30 & 830 & 1900 & 0.74 \\
\hline Chenshen Meigui Garden & 60,102 & 30 & 840 & 1700 & 1.75 \\
\hline Wanke Apartment & 60,949 & 30 & 360 & 2400 & 2.5 \\
\hline Ludi Chunshen Garden & 58,859 & 30 & 830 & 2800 & 1 \\
\hline Shennan Huayuan & 58,445 & 30 & 1500 & 2400 & 0.3 \\
\hline Jiangnan Mansion & 57,746 & 30 & 1400 & 2500 & 1.5 \\
\hline Xinkongjian Jiayuan & 54,711 & 30 & 1600 & 2100 & 0.8 \\
\hline Jinmei Xinyuan & 66,760 & 31 & 950 & 2900 & 3.15 \\
\hline Zhongcheng Luyuan & 65,216 & 31 & 300 & 2800 & 1.05 \\
\hline Changxing Jiayuan & 61,728 & 31 & 40 & 2800 & 0.8 \\
\hline Chunxin Garden & 51,397 & 31 & 1900 & 2200 & 0.6 \\
\hline Lianhua Xin Village & 49,436 & 31 & 2100 & 2300 & 0.45 \\
\hline Miaohuading Garden & 60,597 & 32 & 1700 & 2600 & 1.68 \\
\hline Bilinwan Apartment & 59,376 & 32 & 780 & 2400 & 1.6 \\
\hline Dongfang Garden (First) & 60,631 & 32 & 1300 & 2200 & 1.8 \\
\hline Baixue Gongzhu & 60,526 & 32 & 760 & 2300 & 1.5 \\
\hline Fuli Apartment & 57,046 & 32 & 1900 & 2700 & 0.8 \\
\hline South Bilinwan Garden & 55,758 & 32 & 1100 & 2500 & 1.5 \\
\hline Wantai Garden & 54,724 & 32 & 920 & 1800 & 0.8 \\
\hline Yuanyi Xin Garden & 52,111 & 32 & 810 & 1400 & 0.6 \\
\hline Huabao Garden & 50,342 & 32 & 510 & 1600 & 0.85 \\
\hline Villa Royal & 55,729 & 34 & 970 & 2800 & 1.5 \\
\hline Haoshi Fenghuang & 55,130 & 34 & 800 & 3500 & 1.13 \\
\hline Jianqiao Jinyuan & 50,089 & 34 & 980 & 2400 & 2 \\
\hline YIndu Xincun & 49,073 & 34 & 420 & 3100 & 0.55 \\
\hline Dongyuan Milan & 55,664 & 34 & 1500 & 1000 & 1.6 \\
\hline $\begin{array}{c}\text { Jinmin Wenbo Shuijing } \\
\text { Apartment }\end{array}$ & 55,218 & 34 & 1000 & 570 & 2.15 \\
\hline Haoshi Yinyuan & 55,213 & 34 & 810 & 1700 & 2 \\
\hline Tianlai Garden & 53,720 & 34 & 1600 & 1200 & 3.2 \\
\hline
\end{tabular}




\section{Continued}

\begin{tabular}{|c|c|c|c|c|c|}
\hline Jianqiao Xin Garden & 47,227 & 34 & 1000 & 110 & 1.85 \\
\hline Villa Saint Teresa & 46,103 & 34 & 570 & 1500 & 3 \\
\hline Xinyin Garden & 43,878 & 34 & 650 & 1600 & 0.52 \\
\hline Baoshan $6^{\text {th }}$ Village & 49,024 & 35 & 430 & 2900 & 0.7 \\
\hline Zhongyi Garden & 50,867 & 35 & 370 & 2500 & 1 \\
\hline Baoshan $2^{\text {nd }}$ Village & 49,691 & 35 & 530 & 2600 & 0.2 \\
\hline Baoshan $10^{\text {th }}$ Village & 45,657 & 35 & 920 & 1900 & 1 \\
\hline Hiajiang $2^{\text {nd }}$ Village & 45,633 & 35 & 1200 & 3000 & 0.4 \\
\hline Haijiang Apartment & 43,649 & 35 & 650 & 2900 & 1.3 \\
\hline Baoshan $1^{\text {st }}$ Village & 40,304 & 35 & 510 & 2900 & 1.6 \\
\hline Kaiyuan Jingjiang Garden & 46,808 & 36 & 350 & 1600 & 1 \\
\hline Baoshan $3^{\text {th }}$ Village & 46,706 & 36 & 170 & 1300 & 0.6 \\
\hline Baogang $7^{\text {th }}$ Village & 46,809 & 36 & 880 & 570 & 0.3 \\
\hline Linjiang $4^{\text {th }}$ Village & 49,490 & 36 & 140 & 1400 & 1.2 \\
\hline Baocheng $2^{\text {nd }}$ Village & 47,476 & 36 & 260 & 1200 & 0.6 \\
\hline Shuishang Xin Village & 46,711 & 36 & 740 & 740 & 0.24 \\
\hline Baogang $11^{\text {th }}$ Village & 46,178 & 36 & 680 & 1000 & 0.3 \\
\hline Baogang 1st Village & 49,293 & 33 & 680 & 760 & 0.6 \\
\hline Baogang $5^{\text {th }}$ Village & 45,671 & 33 & 780 & 260 & 0.3 \\
\hline Jiabao Mengzhiwan & 43,407 & 37 & 1100 & 2100 & 3 \\
\hline Xincheng Youhuocheng & 40,099 & 37 & 550 & 1400 & 2.15 \\
\hline Baoli Haishang Wuyuehua & 40,876 & 40 & 1120 & 2900 & 1.7 \\
\hline Jianing Fang & 40,788 & 40 & 360 & 2100 & 0.9 \\
\hline Jiafu Neighborhood & 39,061 & 40 & 642 & 2000 & 1 \\
\hline Huilong Apartment & 40,416 & 42 & 690 & 2500 & 1.5 \\
\hline Liyuan $1^{\text {st }}$ Village & 40,829 & 42 & 173 & 2000 & 0.8 \\
\hline Chengnan Xin Village & 40,244 & 42 & 1100 & 2300 & 0.45 \\
\hline Qiuxia Apartment & 32,281 & 42 & 124 & 2300 & 0.5 \\
\hline Renle $4^{\text {th }}$ Village & 39,697 & 39 & 150 & 6700 & 0.8 \\
\hline Songshi Garden & 39,634 & 39 & 880 & 6900 & 1.35 \\
\hline Songle Garden & 37,460 & 39 & 1500 & 6800 & 0.4 \\
\hline Xilin Neighborhood & 36,527 & 39 & 640 & 7000 & 0.4 \\
\hline Baiyang Garden & 33,451 & 39 & 1600 & 1500 & 0.56 \\
\hline Renle $3^{\text {rd }}$ Village & 33,108 & 39 & 220 & 910 & 0.8 \\
\hline Ronghui Apartment & 32,064 & 39 & 600 & 2100 & 0.8 \\
\hline Dingxin Apartment & 38,606 & 41 & 200 & 800 & 0.6 \\
\hline Yusheng Haoyuan Apartment & 37,320 & 41 & 330 & 820 & 1 \\
\hline
\end{tabular}




\section{Continued}

\begin{tabular}{|c|c|c|c|c|c|}
\hline Mingfeng Apartment & 35,988 & 41 & 1000 & 530 & 0.65 \\
\hline Tianle Neighborhood & 35,696 & 41 & 970 & 1400 & 0.35 \\
\hline Gongjie Garden & 34,908 & 41 & 1000 & 1100 & 1.75 \\
\hline Laidun Neighborhood & 35,803 & 41 & 4600 & 1700 & 1.4 \\
\hline Tianhong $6^{\text {th }}$ Village & 34,292 & 41 & 2000 & 2000 & 0.8 \\
\hline Songyun Shuiyuan & 35,568 & 41 & 1500 & 2000 & 1.35 \\
\hline Tianhong $4^{\text {th }}$ Village & 35,268 & 41 & 1900 & 2100 & 1.2 \\
\hline Dajiang Garden & 34,461 & 41 & 1200 & 1300 & 0.6 \\
\hline Jiangzhong Garden & 36,457 & 38 & 2000 & 2100 & 0.8 \\
\hline Jianghong Garden & 36,102 & 38 & 1700 & 5000 & 0.8 \\
\hline Jiufeng Neighborhood & 36,231 & 38 & 2400 & 5800 & 0.7 \\
\hline Fangzhouyuan $3^{\text {rd }}$ Village & 34,574 & 43 & 2100 & 5100 & 0.6 \\
\hline Tongbo Neighborhood & 33,461 & 43 & 1000 & 5800 & 0.35 \\
\hline Rongnan Garden & 35,333 & 43 & 1200 & 7000 & 0.5 \\
\hline Fangzhouyuan $4^{\text {th }}$ Village & 35,754 & 43 & 2100 & 5200 & 0.6 \\
\hline Rongnan Xinyuan & 35,233 & 43 & 1200 & 7100 & 0.45 \\
\hline
\end{tabular}

(b)

\begin{tabular}{|c|c|c|c|c|c|}
\hline Neighborhood & Green Coverage Ratio & Elevator & Residential Area & Floor Area Ratio & Building Age \\
\hline Huarun Waitan Jiuli Neighborhood & 40 & 1 & 245 & 3.1 & 6 \\
\hline Haiqi Garden & 35 & 1 & 119 & 3.6 & 14 \\
\hline Shanghaitan Garden & 40 & 1 & 104 & 3.3 & 12 \\
\hline Changfeng Garden & 40 & 1 & 93 & 4 & 10 \\
\hline Yuelai Neighborhood & 20 & 1 & 42 & 2 & 22 \\
\hline Yangguan Cuizu Garden & 35 & 1 & 117 & 3.8 & 12 \\
\hline Yangguanli/Yangguan Neighborhood & 35 & 1 & 121 & 3.5 & 13 \\
\hline Xueshui Garden & 35 & 1 & 58 & 3.5 & 18 \\
\hline Fuxin Building & 30 & 1 & 107 & 3.8 & 16 \\
\hline Shilin Hua Garden & 35 & 1 & 142 & 3.5 & 10 \\
\hline Sinan Mansion & 40 & 1 & 186 & 1.13 & 5 \\
\hline Yandang Building & 30 & 1 & 138 & 2 & 32 \\
\hline Xiangshan Lishe Apartment & 40 & 1 & 152 & 3 & 3 \\
\hline Ruixue Building & 30 & 1 & 60 & 3 & 39 \\
\hline Road Shangxi Nan, Lane 271 & 30 & 1 & 44 & 3 & 18 \\
\hline Yongye Apartment & 20 & 1 & 151 & 1.6 & 9 \\
\hline Huilong Apartment & 36 & 1 & 98.9 & 4.36 & 15 \\
\hline Shunfeng Apartment & 25 & 1 & 58 & 1.5 & 22 \\
\hline Taoyuanxin Garden & 42 & 1 & 138.5 & 3 & 15 \\
\hline
\end{tabular}




\section{Continued}

\begin{tabular}{|c|c|c|c|c|c|}
\hline Baihui Building & 30 & 1 & 94 & 2.8 & 22 \\
\hline Mengxi Neighborhood & 25 & 0 & 33 & 2.2 & 21 \\
\hline Singapore Garden & 40 & 1 & 91 & 2 & 18 \\
\hline Fuxingjia Garden & 40 & 1 & 170 & 3.5 & 14 \\
\hline Yuntai Apartment & 38 & 1 & 124 & 4.5 & 18 \\
\hline Yinxin Garden & 35 & 1 & 153 & 3.6 & 16 \\
\hline Beimengsan Neighborhood & 30 & 0 & 30 & 2 & 21 \\
\hline Lili Neighborhood & 30 & 0 & 50 & 2 & 20 \\
\hline Chengshen Apartment & 20 & 1 & 103 & 2.6 & 17 \\
\hline Yaojiang Garden & 30 & 1 & 126 & 2.3 & 13 \\
\hline Nankang Apartment & 30 & 1 & 75 & 1.6 & 20 \\
\hline Zhongnan Neighborhood & 35 & 0 & 52 & 1.5 & 18 \\
\hline Huixiang Apartment & 35 & 1 & 73 & 2.3 & 19 \\
\hline Jinzhong Garden & 25 & 1 & 85 & 2 & 20 \\
\hline Shimin Neighborhood & 32 & 0 & 45 & 1 & 52 \\
\hline Honghui Neighborhood & 35 & 1 & 124 & 4.35 & 12 \\
\hline Jianle Neighborhood & 30 & 0 & 57 & 1 & 33 \\
\hline Danshuiwan Garden & 41 & 1 & 129 & 2 & 10 \\
\hline Jiande Neighborhood & 30 & 1 & 99 & 1.8 & 15 \\
\hline Madang Neighborhood & 23 & 1 & 57 & 4.1 & 25 \\
\hline Danshui Apartment & 20 & 1 & 124 & 3.77 & 17 \\
\hline Bashi Neighborhood & 20 & 0 & 39 & 1.2 & 24 \\
\hline Fuxing Neighborhood & 30 & 1 & 141 & 2 & 19 \\
\hline Ruijin garden & 35 & 1 & 90 & 2.5 & 19 \\
\hline Changjiang Apartment & 35 & 1 & 60 & 1.8 & 78 \\
\hline Huasheng Mansion & 40 & 1 & 112 & 4.3 & 12 \\
\hline East Huihai Apartment & 45 & 1 & 126 & 5 & 11 \\
\hline Taoyuan Neighborhood & 25 & 0 & 38 & 1.5 & 22 \\
\hline Zhongfu Huayuan Yong Apartment & 30 & 1 & 68 & 2 & 15 \\
\hline Haichao Neighborhood & 35 & 0 & 40 & 4.3 & 28 \\
\hline Road Haichao, Lane 256 & 35 & 0 & 35 & 2 & 27 \\
\hline Nanpu Apartment & 26 & 1 & 85 & 2.57 & 18 \\
\hline Renbao Apartment & 30 & 1 & 85 & 2.5 & 17 \\
\hline Baihui Apartment & 35 & 1 & 103 & 3 & 14 \\
\hline Jinri Shijia Neighborhood & 35 & 1 & 70 & 3.1 & 11 \\
\hline Haizhou Guoji Garden & 38 & 1 & 142 & 2.5 & 12 \\
\hline Tianzhushan Neighborhood & 25 & 0 & 42 & 1.8 & 24 \\
\hline
\end{tabular}




\section{Continued}

\begin{tabular}{|c|c|c|c|c|c|}
\hline Quxi Village & 20 & 0 & 48 & 1.8 & 53 \\
\hline Liyuan Village & 25 & 0 & 18 & 2.2 & 29 \\
\hline Yilv Apartment & 30 & 0 & 86 & 1.2 & 21 \\
\hline Dingda Apartment & 30 & 0 & 84 & 1.8 & 7 \\
\hline Dongyu Garden & 20 & 1 & 114 & 2.5 & 15 \\
\hline Santana Building & 36 & 1 & 78 & 1.9 & 23 \\
\hline Road Mengzi, Lane 395 & 30 & 0 & 36 & 2.2 & 29 \\
\hline New Jiangnan Shiji Garden & 45 & 1 & 100 & 4 & 16 \\
\hline Daxin Building & 25 & 1 & 75 & 1.8 & 25 \\
\hline Jiayuting & 28 & 1 & 141 & 3.65 & 3 \\
\hline Shijia Neighborhood & 30 & 0 & 68 & 1.2 & 26 \\
\hline Road Jiashan, Lane 232 & 35 & 0 & 48 & 1.6 & 36 \\
\hline Wutong Garden & 25 & 1 & 84 & 2 & 19 \\
\hline Dingxin Building & 20 & 1 & 162.15 & 2 & 19 \\
\hline $\begin{array}{l}\text { Oriental Manhattan,Shangdong } \\
\text { Neighborhood }\end{array}$ & 40 & 1 & 181 & 1.26 & 13 \\
\hline Zhongyuan Village & 35 & 0 & 35 & 1.6 & 32 \\
\hline Wending Tianxia Garden & 35 & 1 & 120.7 & 3.5 & 14 \\
\hline Taide Garden & 40 & 1 & 92 & 2.5 & 17 \\
\hline Road Yude, Lane 66 & 25 & 1 & 38.89 & 2 & 22 \\
\hline Oriental Manhattan & 40 & 1 & 85 & 4 & 14 \\
\hline Jinghui Garden & 40 & 1 & 80 & 1.4 & 19 \\
\hline Yifeng Garden & 50 & 1 & 55.23 & 2 & 11 \\
\hline Road Xuhong, Lane 110 & 25 & 0 & 54 & 1.5 & 29 \\
\hline Shiye Apartment & 20 & 1 & 90.36 & 2.5 & 24 \\
\hline Taide Hua Garden & 35 & 1 & 96 & 3.85 & 17 \\
\hline Kaixuan Haoting & 30 & 1 & 106 & 4.6 & 11 \\
\hline Kaihua Apartment & 10 & 0 & 100 & 3 & 17 \\
\hline Road Kangping, Lane 207 & 25 & 0 & 75 & 1.2 & 32 \\
\hline Gong'an Building & 40 & 1 & 46 & 2.5 & 24 \\
\hline Tianping Neighborhood & 33 & 1 & 52 & 1.5 & 21 \\
\hline Jingfu Garden & 35 & 1 & 205 & 2.37 & 14 \\
\hline Road Gao'an, Lane 9 & 35 & 0 & 44.6 & 1.2 & 31 \\
\hline Road Henshang, Lane 696 & 20 & 0 & 64.8 & 1.2 & 37 \\
\hline Huaqiang Apartment & 18 & 1 & 49 & 1.8 & 24 \\
\hline Wuxing Apartment & 36 & 1 & 72.35 & 3 & 18 \\
\hline Yi Garden & 12 & 0 & 33 & 1.5 & 32 \\
\hline Yueyang Building & 35 & 1 & 40 & 1.2 & 30 \\
\hline
\end{tabular}




\section{Continued}

\begin{tabular}{|c|c|c|c|c|c|}
\hline Road Yueyang, Lane 200 & 30 & 0 & 71.4 & 2 & 18 \\
\hline Baroque Palace & 35 & 1 & 95 & 5 & 16 \\
\hline Gaoxing Apartment & 10 & 1 & 66 & 3.8 & 14 \\
\hline Zhongkai Chengshi Zhiguang & 35 & 1 & 404 & 3.5 & 3 \\
\hline Dongfang Shikong Apartment & 36 & 1 & 45 & 3.2 & 13 \\
\hline Hongqiao Leting Pojin & 40 & 1 & 152.13 & 3.8 & 14 \\
\hline Nandan Neighborhood & 15 & 0 & 36.17 & 1.1 & 23 \\
\hline Minghui Garden & 38 & 1 & 96.45 & 2.4 & 14 \\
\hline Kaixuan $1^{\text {st }}$ village & 25 & 0 & 40 & 1.6 & 27 \\
\hline Fannan Neighborhood & 28 & 0 & 58 & 1.6 & 22 \\
\hline Nanyi Garden & 25 & 0 & 66 & 5.5 & 21 \\
\hline Yanggang Mansion & 41 & 1 & 106 & 4 & 16 \\
\hline Jiaoda Apartment & 32 & 1 & 80 & 3 & 17 \\
\hline Dongfang Paris Garden & 61 & 1 & 150 & 5.68 & 16 \\
\hline Yongtai Neighborhood & 20 & 0 & 71.8 & 0.8 & 30 \\
\hline Mingyuan Shiji City & 30 & 1 & 166.37 & 3.9 & 13 \\
\hline Baoli Xi'an & 41 & 1 & 200 & 2.5 & 1 \\
\hline Haibo Xuhui Fudi & 30 & 1 & 150 & 2.3 & 3 \\
\hline Shanghaiwan Haoting & 35 & 1 & 219.53 & 3.23 & 7 \\
\hline Linjiang Haoyuan & 35 & 1 & 143 & 2.94 & 9 \\
\hline Xuhui Garden & 35 & 1 & 300 & 3.13 & 12 \\
\hline Shuangfeng Neighborhood & 30 & 0 & 41 & 1.2 & 22 \\
\hline Shenhang Neighborhood & 30 & 0 & 36.05 & 1.2 & 32 \\
\hline Wannan fifth Village & 30 & 0 & 40.6 & 1.8 & 36 \\
\hline Xiechang Neighborhood & 30 & 1 & 74 & 2.3 & 22 \\
\hline Wannan sixth Village & 30 & 0 & 41 & 1.8 & 31 \\
\hline Dong'an Garden & 35 & 0 & 90 & 1.8 & 20 \\
\hline Huarong Neighborhood & 25 & 1 & 69 & 3 & 19 \\
\hline Meike Apartment & 30 & 0 & 70 & 1.6 & 26 \\
\hline Dongan fourth Village & 35 & 0 & 38.48 & 0.38 & 37 \\
\hline Dong'an $2^{\text {nd }}$ Village & 30 & 0 & 32.8 & 1.98 & 41 \\
\hline Shuxiang Yiju & 35 & 1 & 81.16 & 3 & 9 \\
\hline $\begin{array}{l}\text { Shanghai Middle School Neighbor- } \\
\text { hood }\end{array}$ & 30 & 0 & 44 & 1.2 & 21 \\
\hline Xinluo Garden & 33 & 0 & 132.93 & 1.6 & 11 \\
\hline Changqiao $5^{\text {th }}$ Village & 35 & 0 & 43 & 1.8 & 26 \\
\hline Guanghua Garden & 30 & 0 & 82.77 & 2 & 22 \\
\hline Changqiao $1^{\text {st }}$ Village & 35 & 0 & 46.2 & 1.45 & 28 \\
\hline
\end{tabular}




\section{Continued}

\begin{tabular}{|c|c|c|c|c|c|}
\hline Zhonghong Huizhiyuan & 36 & 1 & 126.5 & 2.3 & 11 \\
\hline Kehui Jingyuan & 40 & 1 & 72.41 & 2.5 & 13 \\
\hline Zhonghai Xinyuan & 40 & 1 & 145 & 2.8 & 15 \\
\hline Hebin Guoji Apartment & 40 & 1 & 87.18 & 2.5 & 9 \\
\hline Mingjia Garden & 34 & 1 & 106.32 & 3.5 & 16 \\
\hline Caoxi $3^{\text {rd }}$ Village & 35 & 0 & 56 & 2.8 & 29 \\
\hline Xuejiazhai & 35 & 0 & 35.9 & 1.5 & 22 \\
\hline Zishuyuan & 45 & 1 & 101 & 2.1 & 18 \\
\hline Road Qinzhou, Lane 111 & 50 & 0 & 72.76 & 2 & 19 \\
\hline Road Longwu, Lane 11 & 40 & 0 & 65 & 2.1 & 23 \\
\hline Xuhui Apartment & 40 & 1 & 94.52 & 3 & 12 \\
\hline Huafu Apartment & 30 & 0 & 49.42 & 5 & 22 \\
\hline Caoxi $1^{\text {st }}$ Village & 26 & 0 & 40.6 & 2.5 & 38 \\
\hline Longcao Building & 35 & 1 & 94.49 & 1.8 & 24 \\
\hline Aijian Garden & 40 & 0 & 152 & 2 & 13 \\
\hline Tianlin $11^{\text {th }}$ Village & 29 & 0 & 51.86 & 5 & 31 \\
\hline Kehua Apartment & 30 & 0 & 178 & 4 & 178 \\
\hline Tianlin $12^{\text {th }}$ Village & 30 & 0 & 49.52 & 2 & 14 \\
\hline Yibiao Xin Village & 20 & 0 & 33.51 & 1.8 & 25 \\
\hline Tianlin $14^{\text {th }}$ Village & 30 & 0 & 37 & 2 & 29 \\
\hline Huading Guangchang & 30 & 1 & 114 & 1.6 & 15 \\
\hline Tianlin Tiyu Apartment & 45 & 1 & 91 & 1.6 & 19 \\
\hline Qinzhou Aparment & 35 & 1 & 69.76 & 2.3 & 21 \\
\hline Fuyuan Neighborhood & 20 & 1 & 70 & 2.5 & 28 \\
\hline Tianlin Xin Garden & 35 & 1 & 68 & 2 & 23 \\
\hline QinzhouXin Garden & 35 & 1 & 77 & 1.7 & 21 \\
\hline Tianran Ju & 41 & 1 & 157 & 1.42 & 13 \\
\hline Yuannan $3^{\text {rd }}$ Village & 30 & 0 & 32 & 1.6 & 22 \\
\hline Yuannan 1st Village & 32 & 0 & 43 & 1.7 & 28 \\
\hline Yuannan $2^{\text {nd }}$ Village & 28 & 0 & 46 & 1.7 & 25 \\
\hline Bailong Neighborhood & 30 & 0 & 43 & 2.2 & 21 \\
\hline Zhongheng Garden & 30 & 0 & 49 & 2.14 & 18 \\
\hline Haishang Huating & 40 & 1 & 109 & 1.7 & 12 \\
\hline Changqing Fan & 10 & 0 & 59 & 1 & 23 \\
\hline Zijin Garden & 40 & 0 & 112.19 & 2.5 & 16 \\
\hline Changxin Garden & 30 & 0 & 40.33 & 2.1 & 24 \\
\hline Shouyi Fang & 14 & 1 & 81 & 1.5 & 21 \\
\hline
\end{tabular}




\section{Continued}

\begin{tabular}{|c|c|c|c|c|c|}
\hline Wanxiang Garden & 30 & 0 & 96 & 1.6 & 17 \\
\hline Chahua Garden & 34 & 0 & 66.98 & 1.3 & 23 \\
\hline Road Weat Guilin, Lane 101 & 43 & 0 & 106.2 & 2.3 & 16 \\
\hline Changfeng Fang & 31 & 0 & 41 & 2.8 & 23 \\
\hline Guiping Neighborhood & 30 & 0 & 83 & 2.3 & 20 \\
\hline Changhong Fang & 45 & 0 & 73 & 1.2 & 25 \\
\hline Lan Ting & 35 & 1 & 271.16 & 5.3 & 10 \\
\hline Jiali Huating & 53 & 1 & 180.9 & 5 & 14 \\
\hline Dingxiang Apartment & 20 & 0 & 79.8 & 4.35 & 20 \\
\hline Jianghua Jidian Building & 32 & 1 & 35 & 2 & 30 \\
\hline Dongfang Yayuan & 30 & 1 & 94.83 & 5.3 & 16 \\
\hline Xinhai Neighborhood & 18 & 0 & 41 & 2.8 & 41 \\
\hline Yanwu Jidian Building & 30 & 1 & 49 & 2.1 & 26 \\
\hline Jiaxin Chengshi Apartment & 45 & 1 & 130 & 0.7 & 19 \\
\hline Qishan Village & 30 & 0 & 221 & 1.8 & 31 \\
\hline Yuyuan Mansion & 45 & 1 & 121 & 1.8 & 10 \\
\hline Nanhui Neighborhood & 30 & 0 & 38 & 1.6 & 22 \\
\hline Road Xuanhua, Lane 268 & 30 & 1 & 59.52 & 1.2 & 31 \\
\hline Xuanhua Neighborhood & 28 & 0 & 54 & 0.9 & 27 \\
\hline Fu'an Neighborhood & 35 & 1 & 68.19 & 2.2 & 29 \\
\hline Haixin Huayuan & 25 & 1 & 78.9 & 3.5 & 19 \\
\hline Zhongbao Apartment & 70 & 1 & 160.5 & 2.43 & 17 \\
\hline Gubei Guoji Garden & 56 & 1 & 163.97 & 3 & 10 \\
\hline Gubei Zhongyang Garden & 40 & 1 & 159 & 3 & 13 \\
\hline Yucui Haoting & 50 & 1 & 114 & 3.5 & 8 \\
\hline Gubei Ruishi Garden & 50 & 1 & 125.68 & 3 & 10 \\
\hline Jinse Beilawei & 40 & 1 & 117 & 2.71 & 9 \\
\hline Hualijiazu Gubei Garden & 51 & 1 & 138 & 2.9 & 11 \\
\hline Gubei Guoji Plaza & 50 & 1 & 153 & 2.5 & 10 \\
\hline Qiangsheng Gubei Garden & 51 & 1 & 161 & 3.8 & 9 \\
\hline Gubei Jianian Garden & 60 & 1 & 171 & 1.95 & 11 \\
\hline Raofeng Jiayuan & 35 & 1 & 78.35 & 4.66 & 12 \\
\hline Changxin Neighborhood & 30 & 1 & 65.21 & 1.2 & 27 \\
\hline Jinyang Neighborhood & 35 & 0 & 107.81 & 1.2 & 29 \\
\hline Liyuan Kaixuan Neighborhood & 35 & 0 & 75.2 & 1.98 & 17 \\
\hline Wanhua Neighborhood & 28 & 1 & 76.35 & 0.8 & 25 \\
\hline Huayuancun Yayuan & 31 & 1 & 112.07 & 3.42 & 14 \\
\hline
\end{tabular}




\section{Continued}

\begin{tabular}{|c|c|c|c|c|c|}
\hline Huaxin Neighborhood & 32 & 0 & 58 & 1.2 & 29 \\
\hline Daming Neighborhood & 12 & 0 & 59 & 5.6 & 24 \\
\hline Wanhang Neighborhood & 30 & 1 & 87.69 & 2 & 21 \\
\hline Xinglian Building & 30 & 1 & 53.25 & 1.2 & 17 \\
\hline Zhaofeng Garden & 15 & 1 & 170 & 2.1 & 19 \\
\hline Changning 88 Jinting & 50 & 1 & 92.29 & 3.17 & 5 \\
\hline Changjiang Neighborhood & 35 & 1 & 79.52 & 2.3 & 22 \\
\hline Road Changning, Lane 234 & 24 & 0 & 51 & 2.5 & 29 \\
\hline Yinxin Neighborhood & 35 & 1 & 125.43 & 1.2 & 27 \\
\hline Daqiao Neighborhood & 15 & 0 & 38.5 & 3 & 28 \\
\hline Hongqiao Haoyuan & 35 & 1 & 107 & 3.7 & 10 \\
\hline Tianshan $2^{\text {nd }}$ Village & 35 & 0 & 66.22 & 1.9 & 62 \\
\hline Cuiting & 40 & 0 & 92.47 & 1.6 & 15 \\
\hline Zhongzi Neighborhood & 30 & 1 & 77.8 & 4.5 & 20 \\
\hline Ziyu Building & 20 & 1 & 22 & 2 & 20 \\
\hline Jingming Building & 30 & 1 & 154.63 & 2.5 & 29 \\
\hline Xinshiji Plaza & 20 & 1 & 214.23 & 4.6 & 21 \\
\hline Renheng Hebin Garden & 68 & 1 & 84.84 & 2.69 & 12 \\
\hline Gusong Neighborhood & 28 & 0 & 47.6 & 2.2 & 27 \\
\hline Shuixia Neighborhood & 30 & 0 & 46.8 & 3 & 27 \\
\hline Xinxia Neighborhood & 20 & 0 & 68.3 & 2.1 & 21 \\
\hline Maotai Yayuan & 30 & 1 & 71 & 2 & 24 \\
\hline Chang Yuan & 30 & 1 & 132 & 4 & 12 \\
\hline Wangzui Jinpin & 35 & 1 & 288.73 & 2.8 & 7 \\
\hline Beiwang Neighborhood & 20 & 0 & 54 & 3.2 & 22 \\
\hline Road West Yanan, Lane 548/60 & 30 & 0 & 57 & 1.5 & 22 \\
\hline Huaming Shiji Plaza & 40 & 1 & 137.72 & 3 & 15 \\
\hline Dangdai Xinhua & 30 & 1 & 117.3 & 3.2 & 15 \\
\hline Tiandu Neighborhood & 20 & 0 & 35 & 1.5 & 20 \\
\hline Donghu Mingyuan & 40 & 1 & 103.3 & 1.5 & 12 \\
\hline Yangzha Neighborhood & 36 & 0 & 33 & 1.1 & 27 \\
\hline Xinhua Apartment & 32 & 1 & 129 & 2.5 & 17 \\
\hline Huaqian Apartment & 25 & 0 & 55 & 1.1 & 25 \\
\hline Huagong Apartment & 32 & 0 & 51 & 2 & 32 \\
\hline Xinhua Garden & 40 & 1 & 152 & 2.6 & 20 \\
\hline Road Fahuazhen, Lane 878 & 24 & 1 & 37 & 2.6 & 25 \\
\hline Pujiang Building & 30 & 1 & 108 & 2.8 & 19 \\
\hline
\end{tabular}




\section{Continued}

\begin{tabular}{|c|c|c|c|c|c|}
\hline Taoan Neighborhood & 42 & 0 & 72.54 & 1.5 & 24 \\
\hline Xinshidai Jingting & 45 & 1 & 97 & 1.44 & 12 \\
\hline Tongji Huacheng & 45 & 1 & 92.69 & 1.93 & 10 \\
\hline Hejia Apartment & 37 & 1 & 116.37 & 1.5 & 14 \\
\hline Weilan Chengshi Garden & 51 & 1 & 125 & 1.63 & 11 \\
\hline Huamei Garden & 30 & 0 & 83.52 & 1.2 & 21 \\
\hline Yuxing Garden & 65 & 0 & 124.5 & 1.6 & 15 \\
\hline Shengsong $8^{\text {th }}$ Village & 40 & 0 & 50 & 1.3 & 22 \\
\hline Shengsong $9^{\text {th }}$ Village & 33 & 0 & 82.78 & 1.77 & 19 \\
\hline Shengsong $5^{\text {th }}$ Village & 36 & 0 & 40 & 1.8 & 27 \\
\hline Shengsong 3rd Village & 32 & 0 & 61.48 & 1.5 & 28 \\
\hline Dongyuan Jindu Garden & 35 & 0 & 118 & 1.6 & 14 \\
\hline Huangdu Garden & 45 & 1 & 131 & 1.9 & 13 \\
\hline Dongfang Garden & 32 & 1 & 101 & 2.15 & 8 \\
\hline Puhui Xincheng & 37 & 0 & 47.8 & 1.24 & 24 \\
\hline Xiangge Liyuan & 40 & 1 & 135 & 1.2 & 13 \\
\hline Puhui Apartment & 50 & 0 & 67 & 0.8 & 21 \\
\hline Xueyuan Xin Village & 30 & 0 & 64.53 & 1.2 & 19 \\
\hline Baorong Xin Village & 30 & 0 & 54 & 1.3 & 23 \\
\hline Xiufeng Cuigu & 30 & 0 & 60 & 1.5 & 22 \\
\hline Jintai Apartment & 35 & 0 & 61.86 & 1.5 & 21 \\
\hline Xin Shenhua Moli Garden & 37 & 0 & 64.39 & 1.5 & 19 \\
\hline Chenshen Meigui Garden & 44 & 1 & 100.38 & 1.74 & 10 \\
\hline Wanke Apartment & 38 & 1 & 110 & 1.7 & 12 \\
\hline Ludi Chunshen Garden & 45 & 0 & 128 & 1.5 & 14 \\
\hline Shennan Huayuan & 30 & 0 & 66 & 1.5 & 21 \\
\hline Jiangnan Mansion & 45 & 1 & 91.32 & 2 & 12 \\
\hline Xinkongjian Jiayuan & 50 & 0 & 155 & 2.5 & 13 \\
\hline Jinmei Xinyuan & 36 & 1 & 126 & 1.81 & 6 \\
\hline Zhongcheng Luyuan & 40 & 1 & 53 & 1.72 & 11 \\
\hline Changxing Jiayuan & 38 & 0 & 65 & 1.9 & 17 \\
\hline Chunxin Garden & 40 & 0 & 68 & 1.8 & 13 \\
\hline Lianhua Xin Village & 40 & 0 & 68.96 & 1.36 & 18 \\
\hline Miaohuading Garden & 55 & 1 & 135.6 & 1.7 & 11 \\
\hline Bilinwan Apartment & 48 & 1 & 130.28 & 1.5 & 10 \\
\hline Dongfang Garden（First） & 36 & 0 & 77.7 & 1.5 & 18 \\
\hline Baixue Gongzhu & 40 & 1 & 95.98 & 1.5 & 12 \\
\hline
\end{tabular}




\section{Continued}

\begin{tabular}{|c|c|c|c|c|c|}
\hline Fuli Apartment & 35 & 0 & 90 & 1.5 & 22 \\
\hline South Bilinwan Garden & 40 & 1 & 90 & 1.98 & 12 \\
\hline Wantai Garden & 30 & 0 & 66 & 1.25 & 19 \\
\hline Yuanyi Xin Garden & 30 & 1 & 71 & 1.4 & 21 \\
\hline Huabao Garden & 40 & 0 & 99 & 1.49 & 19 \\
\hline Villa Royal & 45 & 0 & 203.98 & 0.4 & 15 \\
\hline Haoshi Fenghuang & 35 & 1 & 102 & 1.06 & 12 \\
\hline Jianqiao Jinyuan & 40 & 0 & 183 & 0.49 & 14 \\
\hline YIndu Xincun & 35 & 0 & 56.65 & 2.1 & 21 \\
\hline Dongyuan Milan & 35 & 1 & 123.73 & 1.2 & 12 \\
\hline Jinmin Wenbo Shuijing Apartment & 45 & 1 & 88 & 1.1 & 9 \\
\hline Haoshi Yinyuan & 59 & 0 & 182 & 0.7 & 15 \\
\hline Tianlai Garden & 50 & 0 & 293 & 0.36 & 10 \\
\hline Jianqiao Xin Garden & 35 & 1 & 125.36 & 1.2 & 10 \\
\hline Villa Saint Teresa & 62 & 0 & 303 & 0.49 & 11 \\
\hline Xinyin Garden & 35 & 1 & 45 & 1.6 & 16 \\
\hline Baoshan $6^{\text {th }}$ Village & 35 & 0 & 55.5 & 1.61 & 13 \\
\hline Zhongyi Garden & 35 & 1 & 141 & 1.67 & 13 \\
\hline Baoshan $2^{\text {nd }}$ Village & 30 & 0 & 56 & 1.7 & 22 \\
\hline Baoshan $10^{\text {th }}$ Village & 24 & 0 & 99.69 & 1.3 & 20 \\
\hline Hiajiang $2^{\text {nd }}$ Village & 35 & 0 & 51.69 & 1.8 & 21 \\
\hline Haijiang Apartment & 40 & 0 & 99 & 1.7 & 14 \\
\hline Baoshan $1^{\text {st }}$ Village & 28 & 0 & 73 & 1.6 & 18 \\
\hline Kaiyuan Jingjiang Garden & 45 & 0 & 141 & 1.41 & 13 \\
\hline Baoshan $3^{\text {th }}$ Village & 35 & 0 & 167 & 1.5 & 17 \\
\hline Baogang $7^{\text {th }}$ Village & 24 & 0 & 29 & 1.2 & 38 \\
\hline Linjiang $4^{\text {th }}$ Village & 39 & 0 & 119 & 3 & 26 \\
\hline Baocheng $2^{\text {nd }}$ Village & 25 & 0 & 67.49 & 1.5 & 17 \\
\hline Shuishang Xin Village & 24 & 0 & 55 & 1 & 31 \\
\hline Baogang $11^{\text {th }}$ Village & 17 & 0 & 50 & 1 & 32 \\
\hline Baogang 1st Village & 20 & 0 & 35 & 0.72 & 35 \\
\hline Baogang $5^{\text {th }}$ Village & 25 & 0 & 58 & 0.75 & 26 \\
\hline Jiabao Mengzhiwan & 35 & 1 & 110.96 & 1.5 & 2 \\
\hline Xincheng Youhuocheng & 40 & 1 & 90.23 & 2.28 & 5 \\
\hline Baoli Haishang Wuyuehua & 35 & 1 & 56.15 & 1.31 & 8 \\
\hline Jianing Fang & 32 & 0 & 87.51 & 3.2 & 18 \\
\hline Jiafu Neighborhood & 40 & 0 & 94 & 1.36 & 22 \\
\hline
\end{tabular}




\section{Continued}

\begin{tabular}{|c|c|c|c|c|c|}
\hline Huilong Apartment & 35 & 0 & 96 & 2.1 & 20 \\
\hline Liyuan $1^{\text {st }}$ Village & 34 & 0 & 53.14 & 1.85 & 22 \\
\hline Chengnan Xin Village & 34 & 0 & 59.58 & 1.38 & 20 \\
\hline Qiuxia Apartment & 35 & 0 & 87.91 & 1.96 & 22 \\
\hline Renle $4^{\text {th }}$ Village & 30 & 0 & 58 & 1.2 & 19 \\
\hline Songshi Garden & 35 & 0 & 79 & 1.6 & 9 \\
\hline Songle Garden & 35 & 0 & 102 & 1.8 & 13 \\
\hline Xilin Neighborhood & 36 & 0 & 72 & 1.5 & 18 \\
\hline Baiyang Garden & 45 & 0 & 85 & 1.8 & 13 \\
\hline Renle $3^{\text {rd }}$ Village & 30 & 0 & 58 & 1.2 & 23 \\
\hline Ronghui Apartment & 30 & 1 & 32 & 1.6 & 11 \\
\hline Dingxin Apartment & 35 & 0 & 82 & 1.2 & 13 \\
\hline Yusheng Haoyuan Apartment & 40 & 0 & 136 & 8.9 & 10 \\
\hline Mingfeng Apartment & 45 & 1 & 48 & 1.3 & 13 \\
\hline Tianle Neighborhood & 30 & 0 & 81 & 0.8 & 19 \\
\hline Gongjie Garden & 35 & 0 & 95 & 2.4 & 16 \\
\hline Laidun Neighborhood & 70 & 1 & 122 & 1.6 & 5 \\
\hline Tianhong $6^{\text {th }}$ Village & 35 & 0 & 88 & 1.6 & 18 \\
\hline Songyun Shuiyuan & 41 & 1 & 126 & 1.7 & 11 \\
\hline Tianhong $4^{\text {th }}$ Village & 30 & 0 & 66 & 1.6 & 20 \\
\hline Dajiang Garden & 40 & 0 & 89 & 1.55 & 10 \\
\hline Jiangzhong Garden & 35 & 0 & 80 & 1.8 & 17 \\
\hline Jianghong Garden & 32 & 0 & 120 & 0.7 & 16 \\
\hline Jiufeng Neighborhood & 26 & 0 & 72 & 1.5 & 31 \\
\hline Fangzhouyuan $3^{\text {rd }}$ Village & 35 & 0 & 82 & 1.2 & 17 \\
\hline Tongbo Neighborhood & 35 & 0 & 83 & 1.2 & 21 \\
\hline Rongnan Garden & 33 & 0 & 92 & 1.8 & 11 \\
\hline Fangzhouyuan $4^{\text {th }}$ Village & 35 & 0 & 78 & 1.6 & 16 \\
\hline Rongnan Xinyuan & 25 & 1 & 70 & 1.8 & 11 \\
\hline
\end{tabular}

